\title{
Changes in food access by mestizo communities associated with deforestation and agrobiodiversity loss in Ucayali, Peruvian Amazon
}

\author{
Genowefa Blundo-Canto ${ }^{1,2,3}$. Gisella S. Cruz-Garcia ${ }^{4,5}$ • Elise F. Talsma ${ }^{6,7} \cdot$ Wendy Francesconi $^{8} \cdot$ Ricardo Labarta $^{4}$. \\ Jose Sanchez-Choy ${ }^{9} \cdot$ Lisset Perez-Marulanda ${ }^{10} \cdot$ Paula Paz-Garcia $^{4} \cdot$ Marcela Quintero $^{10}$
}

Received: 3 May 2019 / Accepted: 27 February 2020 / Published online: 14 April 2020

(C) The Author(s) 2020

\begin{abstract}
Few longitudinal studies link agricultural biodiversity, land use and food access in rural landscapes. In this paper, we test the hypothesis that, in a context of economic change, cash crop expansion is associated with deforestation, reduced agrobiodiversity and changes in food access. For this purpose, we analysed data collected from the same 53 upland and floodplain mestizo households in Ucayali, Peru, in 2000 and 2015. We found an emerging transition towards less diversified food access coupled with loss of forest cover and reduced agricultural biodiversity. In 2015, diets appeared to rely on fewer food groups, fewer food items, and on products increasingly purchased in the market compared to 2000. Wild fruits and plants were mentioned, but rarely consumed. Agricultural production systems became more specialised with a shift towards commercial crops. Peak deforestation years in the 15 -year period appeared linked with incentives for agricultural expansion. Our results suggest an overall trend from diversified productive and "extractive" systems and more diverse food access, towards specialized productive systems, with less diverse food access and stronger market orientation (both in production and consumption). The assumption in the food and agricultural sciences that increased income and market-orientation is linked to improved food security, is challenged by our integrated analyses of food access, agrobiodiversity, land use and forest cover. Our results highlight the importance of longitudinal, multidimensional, systemic analyses, with major implications for land use, food and health policies. The potential risks of parallel homogenisation of diets and agricultural production systems require interdisciplinary research and policies that promote integrated landscape approaches for sustainable and inclusive food systems.
\end{abstract}

Keywords Food security $\cdot$ Household dietary diversity score $\cdot$ Agrobiodiversity $\cdot$ Ecosystem services $\cdot$ Land use change

Electronic supplementary material The online version of this article (https://doi.org/10.1007/s12571-020-01022-1) contains supplementary material, which is available to authorized users.

Genowefa Blundo-Canto

genowefa.blundo_canto@cirad.fr

Gisella S. Cruz-Garcia

Gisella.CruzGarcia@oxfamnovib.nl

Elise F. Talsma

Elise.talsma@wur.nl

Wendy Francesconi

w.francesconi@cgiar.org

Ricardo Labarta

r.labarta@cgiar.org

\author{
Jose Sanchez-Choy \\ jsanchezc@unia.edu.pe \\ Lisset Perez-Marulanda \\ Lisset.perez@cgiar.org \\ Paula Paz-Garcia \\ p.a.paz@cgiar.org \\ Marcela Quintero \\ m.quintero@ cgiar.org
}

Extended author information available on the last page of the article 


\section{Introduction}

Agricultural biodiversity provides macro- and micro-nutrients which are indispensable for food and nutritional security (Zimmerer et al. 2019), ensures access to food during lean months (Cruz-Garcia and Price 2014; Grivetti and Ogle 2000), and resilience in times of decreased production or economic shocks (Vinceti et al. 2013). Yet, land-use change can alter local food consumption patterns and food systems (Behera et al. 2015). Modern agricultural methods, whose use is currently expanding at forest frontiers, are often associated with reduced agricultural biodiversity and ecosystem services (Frison et al. 2011). Moreover, the relationship between agricultural biodiversity and dietary diversity is complex (Chappell and LaValle 2011; Jones 2017). A study based on a nationally representative survey in Malawi (6623 households) found a positive association between dietary diversity and on-farm crop and livestock diversity, but not with the proportion of self-produced food (Jones et al. 2014). On-farm and market diversity have also been shown to be positively associated with mothers' dietary diversity in Southern Benin (Bellon et al. 2016) and in Tanzania (Keding et al. 2012), and with higher odds of achieving a minimally diverse diet in the Peruvian Andes (Jones et al. 2018). Although a comparison of data for Indonesia, Kenya, Ethiopia and Malawi (Sibhatu et al. 2015) reported that increasing production diversity does not necessarily improve dietary diversity in smallholder farming systems, these results were the subject of debate (Berti 2015).

Farming households make land use decisions based on contextual economic opportunities (Lambin et al. 2001), household characteristics, preferences and risk aversion in imperfect or missing markets (Smale 2005); van Dusen and Taylor 2005), access to roads (Babigumira et al. 2014), ageing and gender (VanWey et al. 2007; Walker et al. 2002). Environmental heterogeneity (Brush 1995), but also cultural identity (Arslan and Taylor 2009), cohesion (Bellon and Hellin 2011), demographic factors, property rights, and education (Radel et al. 2010), influence why and how farming households manage agricultural diversity.

In the Amazon region, one of the most mega-diverse regions on earth (Foley et al. 2007), land use changes have been linked to neoliberal agrarian policies (Arce-Nazario 2007), smallholder resettlement schemes and policy incentives (Bennett et al. 2018), road and infrastructure development (Andersen et al. 2002; Perz et al. 2013), cattle farming and cultivation of illicit crops (Armenteras et al. 2006). Policy and push-pull factors, including access to land, road development and coca production, but also violence and poverty in their former circumstances attracted colonist settlers, called mestizo households (Alvarez and Naughton-Treves 2003; Chavez and Perz 2012; Guevara Salas 2009; Labarta et al. 2008). Cropland expansion has also been identified as a major driver of land cover change (GutiérrezVélez and DeFries 2013), providing high returns especially in areas of previously intact forests (Butler and Laurance 2009), but also threatening ecosystem services (Srinivas and Koh 2016). The Peruvian Amazon, particularly the Ucayali department, has attracted a growing body of literature on land use and socioeconomic change, especially linked to the expansion of oil palm (Bennett et al. 2018; Glinskis and Gutiérrez-Vélez 2019; Gutiérrez-Vélez et al. 2011; Porro et al. 2014). The region is attracting increasing national and international investment, with diverse environmental and social consequences (Frank 2015). Moreover, the Peruvian Amazon has been experiencing increased flooding and drought events, with consequences for crop yields, soil erosion, water availability, and human diseases (Sherman et al. 2016). These dynamics pose potential threats to food security in a region experiencing a nutrition transition where $20 \%$ of children under five suffer from chronic malnutrition (Ambikapathi et al. 2018).

If national policy makers aim to promote sustainable and inclusive development, thereby ensuring food security while protecting ecosystem services, adopting a strategy based on the expansion of agricultural land and specialisation, leading to increased deforestation, does not seem appropriate. More in-depth assessments of the multiple impacts caused by changes in the trajectories of productive systems are certainly needed (Kelley et al. 2017) while few long-term analyses have been conducted on the changes in dietary diversity and agrobiodiversity over time (Jones 2017).

In this paper, we analyse changes in land use, livelihood strategies and food access of upland and floodplain mestizo farming households in the Peruvian Amazon, using longitudinal data from surveys conducted 15 years apart. Our sample partially replicates a case study from 2000 , which aimed to represent the main land uses and livelihood strategies of farming communities in Ucayali (Murray 2006). We tested the hypothesis that in the context of economic and institutional change, expansion of cash crops and farm specialisation are associated with deforestation, reduced agrobiodiversity and changes in human diets. Our results allowed us to identify research gaps and make policy recommendations for highly dynamic rural contexts.

\section{Study area: The Ucayali region}

The department of Ucayali takes its name from the Ucayali River, of Andean origin, which has a meandering $1600 \mathrm{~km}$ course fragmented by a few islands. Two thirds of the population, which, according to 2017 census data, amounted to 496,459 inhabitants, reside in the regional capital, Pucallpa. The population doubled between 1940 and 1960 following the construction of the Federico Basadre highway, which facilitated migration from other regions. The migratory influx between 1981 and 2007 was positive, particularly in the Padre Abad province (Diaz Encinas 2009). After a few years of employing diversified cropping systems, and faced with nutrient loss and soil degradation (Yanggen 2000), settlers often 
switched to more profitable livestock production (Coomes 1996; Fujisaka and White 1998). In addition, the expansion of secondary roads favoured colonisation of forest areas (Dourojeanni et al. 2009). However, in the 1990s, fossil fuel exploration and key exports were encouraged (Perz et al. 2005), while subsidies and policies supporting agricultural prices stopped, and deforestation rates slowed down (Yanggen 2000). Investments in traditional primary sectors such as mining, petroleum and fisheries were later consolidated, along with large scale infrastructure projects, free trade agreements, and incentives for the development of the agroindustry (Pautrat and Merveille 2014).

Agriculture, hunting and forestry represent the main productive activity, amounting to $9.6 \%$ of the gross value added of the department (Cumbicus and Lopez 2017). Agriculture is practiced by family units (classified as small and medium sized farms), in areas along the main rivers and the Federico Basadre road. Although agriculture has played a key role in the economic expansion of Ucayali, the majority of soils (70\%) are suitable for forestry. The main staple crops, including banana, cassava, papaya, rice and maize (Salisbury 2013), accounted for $78 \%$ of agricultural production in 2012, but oil palm, cacao, coffee and camu camu (Myrciaria dubia) have been rapidly expanding (Banco Central de Reserva del Perú 2012). Mestizo families sometimes gather wild food plants from agricultural fields, home gardens, and secondary forests (CruzGarcia and Vael 2017). In addition, hunting is one of the livelihood strategies in the region, but the small number of animals harvested claimed by most hunters suggest hunting is an irregular and opportunistic approach (Francesconi et al. 2018).

In terms of cumulated deforestation, the Ucayali region ranks third in Peru, with 80,349 ha of forest cleared between 2010 and 2014 (Ministerio del Ambiente 2015). In addition, land trafficking is the subject of ongoing controversy (Pautrat 2013; Sierra Praeli 2017), along with increasing agribusiness activities (Amancio 2016). Small scale and large scale oil palm plantations also largely contribute to deforestation (GutiérrezVélez et al. 2011), with large companies sometimes bypassing regional legislation (e.g. see the case of Naranjal in Fort and Borasino 2016; Salazar and Rivadeneyra 2016). According to national statistics, the use of increasing amounts of land has not improved human nutrition. For instance, between 2010 and 2013 one in four children under five was reported to be suffering from chronic malnutrition (Ministerio de Salud 2014).

\section{Methods}

We compared changes in land use and agricultural biodiversity with changes in food access and food sources between 2000 and 2015 in mestizo communities in Ucayali.

In 2000, Murray (2006) conducted a study to understand to what extent child nutrition and health were affected by seasonal ecosystem dynamics. The study used an ecosystem approach to evaluate the complex socio-ecological problems that exist in the Peruvian Amazon using interdisciplinary research and mixed methods at different scales (Waltner-Toews and Kay 2005). In our exploratory analysis, we used the data collected in Murray's study, which included socio-economic characteristics of households, and the use of agrobiodiversity and food consumption data. To evaluate changes after a period of 15 years, we chose a mixed methods approach combining semi-structured household surveys, focus groups, in-depth interviews with key informants, and satellite imagery.

\subsection{Household survey, sampling strategy}

For the 2000 study, four mestizo communities, one floodplain community and three upland communities, along with four indigenous communities were selected to represent the main land use systems and livelihood strategies in Ucayali, with one case for each land use. By 2000, the main land use systems in the mestizo communities were cattle ranching, oil palm, and traditional slash and burn (Fujisaka et al. 1999). A statistical procedure was not used to draw a statistically representative sample for the case study, rather all the households in these communities with children aged 1-10 years were interviewed. These households were considered to be the most vulnerable to recurrent nutrient deficiencies and infectious diseases.

In 2015, researchers from CIAT and IIAP replicated part of the original study by focusing on the selected mestizo communities, including: 1) upland cattle ranchers located in La Unión and on the road between Campoverde and La Unión (referred to in this paper as 'La Unión', identified by Murray as 'cattle ranchers'); 2) upland oil palm growers located in Pueblo Libre and on the road between Pueblo Libre and Maronal (referred to in this paper as 'Pueblo Libre', identified by Murray as 'oil palm growers'); and 3) floodplain slash and burn farmers in Naranjal (Aguaytía River) (Fig. 1). Mestizo households are particularly relevant sources of information, as they account for $75.2 \%$ of the population in Ucayali (INEI 2017).

In October 2014, we located all 174 households in the four mestizo communities surveyed in 2000 . Of these, 80 had emigrated away from the communities and 20 made the personal decision not to take part in the survey, meaning $79 \%$ of households agreed to participate, which is acceptable for household surveys (Groves 2006). One community originally included in the study, Yerbas Buenas, was dropped from the analysis because only 12 households could be identified in 2015 among the 40 surveyed in 2000; the rest had emigrated. Of these 12 households, six chose not to participate in the survey, and in the remaining six, only two had complete data on diets during the Murray survey. Out of all 64 households interviewed, 53 had complete food consumption data in the two collection years, so the analysis presented in this paper is based on these 53 households (Table 1). According to census data from 


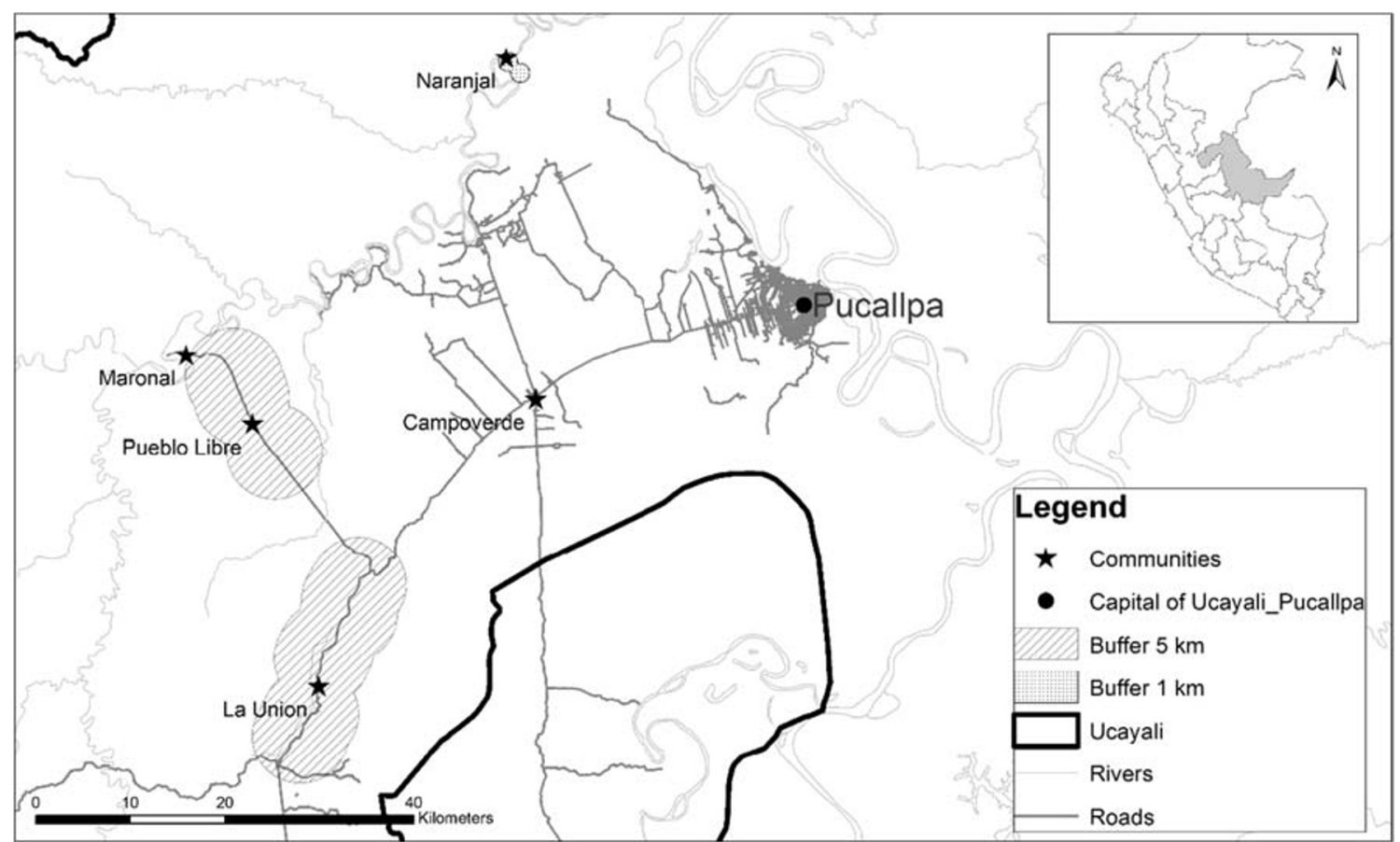

Fig. 1 Partial map of Ucayali with location of sampling sites

$2017,{ }^{1}$ we surveyed about $50 \%$ of households in Pueblo Libre and La Union communities, and about $20 \%$ in Naranjal. In terms of population size, these communities are similar to those in the districts to which they belong. Other recent studies in the Ucayali department, using larger samples to characterise farming households and their practices (Bennett et al. 2018; Francesconi et al. 2018; Glinskis and Gutiérrez-Vélez 2019), present similar findings concerning the demographic and productive features of the households. This reinforces the validity of our data, which, despite the small sample, provide an adequate characterisation of the main livelihood strategies and land uses of non-indigenous households in Ucayali.

Permission to conduct the surveys was granted by the local authorities in Ucayali. All those who participated in the study did so freely and signed a prior informed consent document. The 2000 survey used paper questionnaires, while the 2015 survey was codified and applied on tablets using Open Data Kit (Hartung et al. 2010).

The household surveys were conducted during the peak of the rainy season (January-February) and were repeated in the peak of the dry season (August), in both 2000 and 2015. To be comparable, the same questions were used in both years, and included information on socio-economic characteristics, the use of agrobiodiversity on-farm and in forests (i.e. gathering fruits, medicinal plants, leaves, and hunting animals in secondary or primary forest areas); food and beverage intake was based on free listings, and procurement in the $24 \mathrm{~h}$ preceding

\footnotetext{
${ }^{1}$ https://www.inei.gob.pe/media/MenuRecursivo/publicaciones digitales/Est/ Lib1541/index.htm
}

the survey. Both in the 2000 and in the 2015 surveys, questions concerning food consumption were answered by the person in charge of food preparation, recalling all the steps in food preparation and the ingredients consumed by all members of the household in the preceding $24 \mathrm{~h}$ (qualitative 24-h recall including breakfast, lunch, dinner, and between meals, if shared by the whole household). In the 2015 survey, we added open-ended questions about their reasons for land use change in the preceding 15 years.

The survey included the following socio-economic characteristics: demographic data, education, household assets and sources of income. To characterise agrobiodiversity, farmers were asked about the crops and trees they cultivated, livestock raised, wild plants collected, including leaves and fruits, and wild animals (bushmeat) hunted. In the food intake module, enumerators asked which foods and drinks were consumed by the household for breakfast, lunch, dinner, and between meals. Food items and the source of each item (i.e. purchased in the market, produced in an agricultural field or home garden, extracted from forest or river, received a as gift, donated, or exchanged) were recorded.

\subsection{Focus group discussions and interviews with key informants}

In order to explain community level changes in livelihood strategies, land use and diets, three methods of qualitative data collection were used in the villages surveyed in 2015: participatory rural appraisals (exercises J, K, L, O, S explained in (Schreckenberg et al. 2016); three focus group discussions 


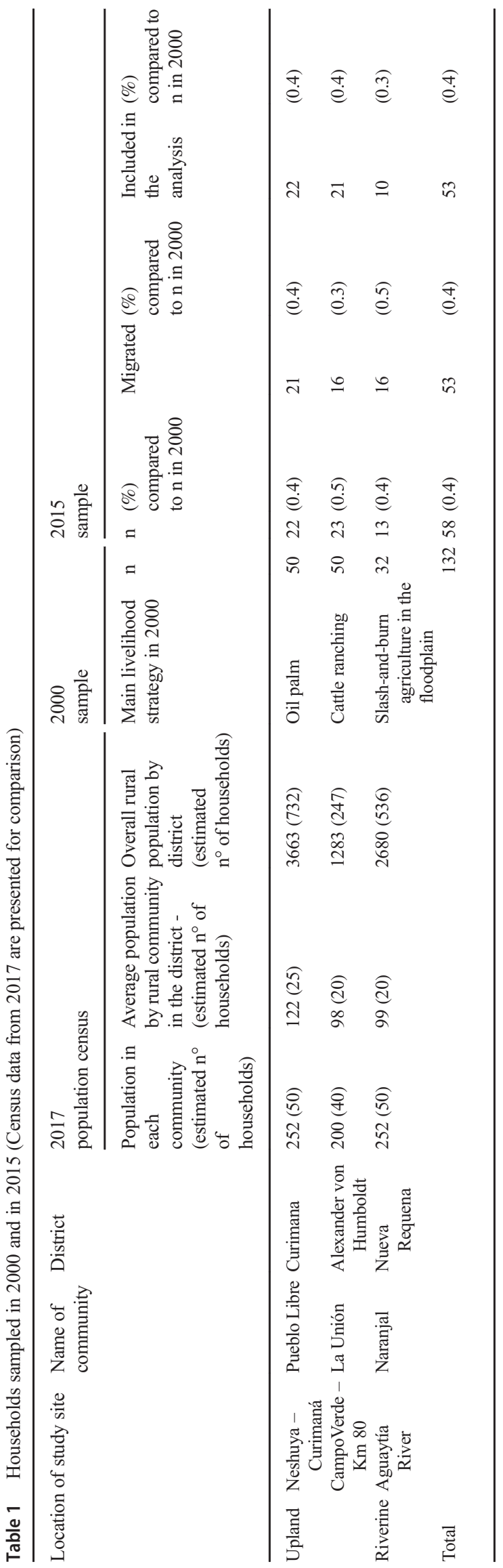

with a total of 24 farmers (explained in Andrieu et al. 2019); and interviews with three experts, one from the regional council, one from the local agency of the national agricultural research institute, and one from the regional agricultural direction.

\subsection{Deforestation maps}

To quantify changes in forest cover over the 15 years period, we downloaded a $30 \mathrm{~m}$ resolution forest cover map dating from 2000, and annual deforestation maps with the same resolution produced between 2001 and 2015, from Global Forest Watch (GFW) (Hansen et al. 2013). Following GFW, areas with vegetation greater than five meters in height are defined as covered by trees. These can include land cover classes from evergreen forests with more than $60 \%$ canopy cover to woody savannas with between $30 \%$ and $60 \%$ canopy cover. To include all land cover classes considered as forests, we identified and selected land cover areas $>=30 \%$ tree canopy, and measured the extent of subsequent deforestation in each community. According to Barber et al. (2014), deforestation in the Amazon usually takes place at an average distance of $5.5 \mathrm{~km}$ from roads, or at a distance of $1 \mathrm{~km}$ from rivers. Hence, we created a $5 \mathrm{~km}$ buffer zone from the road to households located upland, and a $1 \mathrm{~km}$ buffer zone from the central point of riverine households located on each side of the river in Naranjal. Because families in Naranjal are clustered near the village centre, a point buffer was used to measure community impact on nearby forests (Murray 2006, p. 147). By comparing the 2000 forest cover map with the annual deforestation maps, we calculated the annual and accumulated total forest loss per year in hectares and the percentage of remaining tree cover inside the buffer areas using the Tabulate Area function in ArcGIS version 10.1. The function calculates the difference in area in the classifications in two datasets and in our case, compares the changes in land cover between the two survey years to estimate the extent of deforestation. The output is a summary table listing the results (ESRI, R 2011).

\subsection{Data analysis}

We characterised household-level changes in socio-economic characteristics, land uses, agrobiodiversity, food access and sources of food.

To characterise species richness for different types of ecosystem goods, we counted the type and number of crops, livestock, wild animals, wild plants, wild fruits, timber, and forest products used for fuel and fodder, indicators which are commonly used to characterise on-farm and off-farm agrobiodiversity (Jones et al. 2014; Magurran 1988). These indices are the sum of different cultivated crops, livestock, wild animals, wild plants, wild fruits, and other forest products 
mentioned by the households in the rainy and dry seasons in 2000 and 2015.

To characterise the households' food access, we used the household dietary diversity score (HDDS) (Kennedy et al. 2011). The HDDS is a proxy of food access, which is defined as 'the ability to acquire sufficient quality and quantity of food to meet all household members' nutritional requirements for productive lives' (Swindale and Bilinksy 2006). As a proxy, it focuses on household food consumption as the outcome of (adequate or inadequate) food access. The HDDS is the total number of food groups consumed by household members in the $24 \mathrm{~h}$ preceding the survey, with a maximum score of 12. HDDS includes food consumed between meals only if eaten by all family members, and meals outside the home only if shared by the whole family. Following the recommended guidelines, beverages are categorised as follows: juices from fresh fruit in the "fruit" food groups; sodas/sweetened drinks in the "sweet food" groups; coffee and tea in the "spices/condiments and beverages" food group. To characterise food access, we analysed data from the rainy season in 2000 and 2015. Data from the dry season in 2000 were not available for all communities.

To characterise food variety, we analysed differences in the variety of food items consumed in the $24 \mathrm{~h}$ preceding the survey, independently of their food group.

To characterise changes in land use, agricultural biodiversity, food and sources of food, we applied a Wilcoxon signed rank test for paired data and McNemar's chi-square test using Stata (StataCorp 2013). To check if different typologies of households based on characteristics linked to livelihood strategies, food access and land use emerged from the data in 2000 and 2015, we applied a hierarchical cluster analysis. This is a multivariate statistical tool aimed at grouping the statistical units of a population on the basis of their similarity in terms of values taken from the variables observed. This tool allows us to avoid a priori assumptions about existing fundamental typologies but has an exploratory role in the search for latent structures. We chose Ward's hierarchical clustering using a mixture of quantitative and qualitative variables (Maechler 2013). Quantitative variables were previously normalized so their values were within the interval $[0,1]$ and their measurement unit would not affect the computation of similarities. Qualitative variables were categorised into binary values (either 0 or 1). In Ward's method, the distance between two groups is given by the difference between the overall deviation and the sum of the deviations within each group, i.e. the increase in the deviation in each group due to the aggregation in question. The resulting groups are therefore based on minimising the pooled within-group sum of squares. The optimum number of clusters was selected by comparing the elbow method for k-means, the elbow method for partitioning around medoids (PAM) clustering, and the Calinski-Harabasz index. For Ward's clustering, we used a specific function available in the statistical package $\mathrm{R}$ (Agnes function in $\mathrm{R}$ version 3.2.4).

\subsection{Limitations}

In order to reduce bias in our follow-up study, our data collection strategy replicated and expanded the methods used in the Murray study. However, these data are based on recall and on the perspective of the respondent, not on empirical quantification. For instance, we only measured household food access because nutrient adequacy, which requires quantitative weighing of all the items in the 24-h recalls, was beyond the financial means of this study.

The small size of the sample in our follow-up study was partly due to the small population size and partly to emigration, which reflects the economic opportunities offered by the regional capital Pucallpa, and limited our analysis to exploratory methods. We did not model or test farmers' decisionmaking processes, but explored the changes in land use, agricultural biodiversity and food access (measured by the household dietary diversity score) that occurred between 2000 and 2015. In addition, our study was based on only three communities in Ucayali, and thus was not a statistically significant sample representing all communities in Ucayali. However, despite these limitations, we believe that the results of the case studies we present are very important and should not limit our ability to draw relevant interpretations based on the patterns of change observed in our data. We give three reasons for the validity of our analysis. First, the original sample was chosen to characterise contrasted cases of livelihood strategies in upland and floodplain communities in Ucayali, rather than to provide a representative sample of the population in these communities. Within these contrasted cases, the sample was selected to include all families with children aged 1-10 years who lived in the study sites. A total of $56 \%$ of households interviewed in 2000 in the three communities had emigrated in the meantime, and 20 households chose not to take part in the survey. We were able to obtain data for $71.6 \%$ of the remaining population, which is a large percentage of the original population who remained in the study communities. Second, the small sample size also reflects the small population living in these sites. According to the national population censuses in 2007 and 2017, there were 161 households in the three study sites in 2007 and 150 in 2017. Our sample thus represents approximately $35 \%$ of the population in the communities studied. Third, few significant differences were found between the households interviewed in 2000 and reinterviewed, and those who were not re-interviewed in 2015. To show this, we conducted a simple attrition analysis (Lynn 2018) presented in Table 2. Attrition might be selective on household characteristics, potentially introducing bias (Alderman et al. 2001). The analysis showed few significant differences (only three at the 5\% significance level). The data 
Table 2 Main characteristics in 2000 of households which were re-interviewed in 2015 and households which were not re-interviewed

\begin{tabular}{|c|c|c|c|c|c|c|c|}
\hline \multirow[t]{2}{*}{ Variable (year 2000 values) } & \multicolumn{3}{|c|}{$\begin{array}{l}\text { Re-interviewed in } 2015 \\
n=65\end{array}$} & \multicolumn{3}{|c|}{$\begin{array}{l}\text { Not re-interviewed in } 2015 \\
n=109\end{array}$} & \multirow[t]{2}{*}{$\begin{array}{l}\text { Wilcoxon test for } \\
\text { non-paired data }\end{array}$} \\
\hline & Obs & Mean & Std. Dev & Obs & Mean & Std. Dev & \\
\hline Years of education of household members & 65 & 15.95 & 6.44 & 104 & 13.75 & 7.54 & $2.08 * *$ \\
\hline Years of education of household head (HHH) & 65 & 6.00 & 3.66 & 108 & 5.67 & 3.77 & 0.35 \\
\hline Age of $\mathrm{HHH}$ & 62 & 41.32 & 10.64 & 100 & 42.67 & 12.84 & -0.40 \\
\hline Age of household members & 65 & 31.46 & 11.00 & 108 & 30.79 & 12.80 & 0.85 \\
\hline Household size & 65 & 3.49 & 1.57 & 108 & 3.39 & 1.49 & 0.23 \\
\hline Number of members under 18 & 35 & 1.94 & 1.05 & 59 & 1.72 & .86 & 0.86 \\
\hline Number of members under 5 & 5 & 1.2 & .44 & 12 & 1.08 & .28 & 0.66 \\
\hline Number of members who worked off-farm (18 years and older) & 65 & .58 & .89 & 109 & .55 & 1.03 & 0.56 \\
\hline Number of members who work on-farm (18 years and older) & 65 & 3.67 & 1.84 & 109 & 3.09 & 1.96 & $1.88^{*}$ \\
\hline Total land area & 65 & 29.27 & 23.12 & 109 & 21.68 & 22.35 & $2.38 * *$ \\
\hline Area under pastures & 29 & 47.91 & 46.86 & 40 & 39.01 & 47.07 & 1.05 \\
\hline Area under natural pastures & 27 & 28.42 & 26.26 & 36 & 21.67 & 28.94 & 1.29 \\
\hline Area under improved pastures & 22 & 29.18 & 28.88 & 29 & 27.01 & 29.70 & $0.29 *$ \\
\hline Area under mature forest & 43 & 31.34 & 27.93 & 67 & 26.27 & 27.86 & 1.44 \\
\hline Area under successional forest & 61 & 20.44 & 21.37 & 90 & 12.83 & 15.43 & $2.09 * *$ \\
\hline Number of crops cultivated & 65 & 7.03 & 2.95 & 108 & 7.07 & 3.39 & 0.05 \\
\hline La Unión & 23 & 6.34 & 2.63 & 26 & 7.30 & 3.59 & -1.02 \\
\hline Naranjal & 13 & 7.46 & 3.50 & 19 & 8.57 & 3.56 & -0.81 \\
\hline Pueblo Libre & 23 & 6.86 & 2.95 & 38 & 5.92 & 2.62 & 1.07 \\
\hline Yerbas Buenas & 6 & 9.33 & 2.06 & 34 & 7.00 & 3.33 & $1.63 *$ \\
\hline Number of wild fruits collected & 65 & 0.6 & .91 & 109 & .80 & 1.27 & -0.51 \\
\hline \multicolumn{8}{|l|}{ Pearson Chi2 test } \\
\hline Household head works on-farm (\%) & 55 & $84 \%$ & & 87 & $80 \%$ & & 0.62 \\
\hline Own a refrigerator $(\%)$ & 2 & $0 \%$ & & 1 & $0 \%$ & & 1.12 \\
\hline Own a television (\%) & 23 & $35 \%$ & & 28 & $26 \%$ & & 1.84 \\
\hline Households who collect wild leaves & 33 & $50 \%$ & & 62 & $57 \%$ & & 0.61 \\
\hline Households who hunt animals & 26 & $40 \%$ & & 37 & $34 \%$ & & 0.64 \\
\hline Households who extract wood (\%) & 30 & $46 \%$ & & 40 & $37 \%$ & & 1.51 \\
\hline
\end{tabular}

from 2000 show that the households we were unable to reinterview had relatively lower education levels (an average difference of 2 years) and smaller cultivated areas (an average difference of 9 ha, although the average surface area was large), and smaller successional forest areas (an average difference of $8 \mathrm{ha}$ ). This may mean that farmers with less land left due to problems caused by shortened slash and burn cycles, such as lack of nutrient replenishment.

These data suggest that households who did not migrate had access to relatively more land, which might have provided an incentive to stay and pursue their agricultural activities instead of looking for alternatives.

In longitudinal studies, the understanding of how the family life cycle stage affects the results is important. However, we did not add the family life cycle stage of mestizo households (the stages differ with the socio-cultural group) as a variable to be assessed, because this was not part of the original study. But we recommend that future studies include such analysis.

In deforestation analysis, the use of buffer areas to measure forest loss may not always reflect the true impact of humans on forests. For example, measuring forest degradation is currently a limitation when using optical satellite images. Additional satellite technologies (i.e. radar) and processing are required to determine other potential anthropogenic impacts on forest areas, which cannot be captured by analysis of changes in the canopy cover. In addition, as we did not distinguish between primary and secondary forest, we did not account for the potential ecological significance of losing some forest areas versus others. Another possible limitation is that farmers could engage in unsustainable forest activities in remote areas outside our buffer zones. Hence, we may have underestimated the impacts of deforestation caused by the target communities. On the other hand, the long-term nature 
of the present study captures the impacts of communities on their immediate forest surrounding and draws a parallel with their agricultural activities and food access.

\section{Results}

In the following paragraphs, we first briefly describe community-level changes in livelihood strategies and in forest cover. We then look at household-level changes in socioeconomic characteristics, land use and agrobiodiversity, the reasons the farmers gave for land use changes, and household-level changes in food access and sources of food. Finally, we link changes in livelihoods, land use, agrobiodiversity and food access.

\subsection{Community-level changes in land use}

The history of Pueblo Libre has been strongly linked to oil palm. In 1992, the United Nations Office on Drugs and Crime (UNODC) identified Pueblo Libre as one of the target communities for the creation of a cooperative to replace coca cultivation with oil palm. At that point, COCEPU, the central committee of Ucayali palm growers, counted 270 farmers, whereas in 2015, 800 members were managing 6154 ha of oil palm (Ministerio de Agricultura y Riego 2016). Associated producers benefit from favourable credit facilities from banks and rural financial institutions. Sales prices are decreasing (they dropped from US\$220/t in 2004 to US $\$ 157 / t$ in 2014) and are increasingly volatile, but farmers want to continue growing oil palm because it guarantees a certain income. According to the participatory rural appraisals and focus groups, today most farmers in Pueblo Libre buy in the market what they used to grow themselves and have higher perceived food security due to consumption stability, with a diet rich in carbohydrates and protein.

In contrast to Pueblo Libre, livelihoods in La Unión community are geared towards cattle grazing. However, production committees also exist for oil palm, cacao, fish farms, and of course cattle breeding. In contrast to Pueblo Libre, the use of wild plants for consumption and for medical purposes is highest in La Unión, as is the use of forest resources through hunting and small-scale logging activities farmers use to generate additional income.

About 30 years ago, when only 20 families lived in Naranjal, most were cattle breeders, but they progressively switched to maize and plantain, and more recently to oil palm and cacao. Along with La Unión, cacao cultivation projects started in 2008 through a national coca eradication program called DEVIDA. Cacao is the main source of income for many families, and since fewer wild medicinal plants, fruits and wild animals are available for hunting or gathering, the families have been considering selling their timber concession and converting forest land to oil palm production. Supplementary material S1 provides a detailed narrative of the community-level changes we have summarized briefly here.

\subsubsection{Deforestation}

Over a 14-year period (2001-2015), more rapid deforestation and more forest loss was observed in Ucayali than other Amazonian departments in Peru. The department ranks third in Peru for deforestation, with a total of 382,302 ha between 2001 and 2015. The estimated average annual rate of deforestation is 25,486 ha/year, i.e. a $152 \%$ increase in forest loss between 2001 and 2015. Although Fig. 2 focusses on the landscape area along the Federico Basadre highway where most of the deforestation in Ucayali is concentrated, the images also show the rapid and devastating loss of forest cover surrounding the community area.

Zooming to the community level, and using the buffer approach to estimate forest cover change, we calculated a total forest loss of 12,430 ha (30\%) between 2001 and 2015 for all communities. In 2000, 90\% of the buffer zone area at Pueblo Libre was covered with forest (meaning land cover areas equal or greater than $30 \%$ tree canopy), much higher than in $\mathrm{La}$ Unión (42\%) and Naranjal (63\%). However, deforestation in both Pueblo Libre and La Unión have increased steeply and steadily over time (Fig. 3). The annual rate of deforestation in these communities is 467 and 355 ha/year (respectively), which represents an increase of $42 \%$ and $21 \%$ in deforestation compared to the forest area in 2000 (Supplementary material S2). Naranjal lags further behind in terms of forest cover change, with a much slower and lower deforestation rate (6 ha/year), and a smaller proportion (15\%) of forest loss compared to 2000. In all three communities, an increase in forest cover change was observed in 2005, and again in 2009 but this time only in Pueblo Libre and La Unión. A marked increase in deforestation was observed in La Unión and Naranjal in 2012, which in Naranjal remained at a rate of 13 ha/year until 2015.

Our results show that the year 2005 was notable for widespread forest clearing. This first significant peak in forest cover loss appears to be linked to different events. In 2004, a committee involving about 300 families was created in the Aguaytía district to manage a second palm oil extraction plant. At the same time, the fund for the cultivation of oil palm (Fondo de Fomento Palmero) was started, which benefitted about 270 associated producers. Both events were likely followed by land clearing. In the same year, palm oil reached its highest price in the study period (US\$220/t), which likely encouraged farmers to increase their land under oil palm.

The second deforestation peak occurred in 2009. A new oil palm processing plant became operational in 2008, which processed oil produced in 4562 ha of oil palms. In the same 

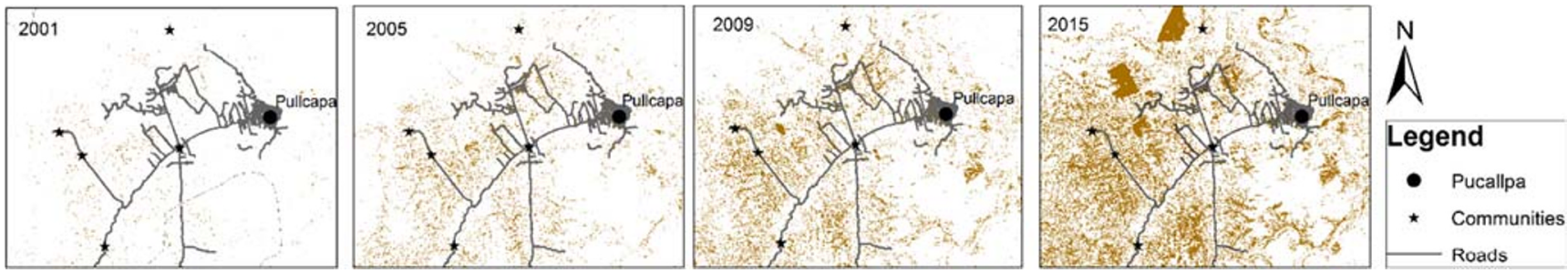

Fig. 2 Forest cover loss over time (between 2001 and 2015) at the study site in Ucayali, Peru

year, the regional government offered a monetary incentive for non-associated oil palm growers to invest in oil palm on 5 ha of land per producer, and the coca eradication program started operating in Naranjal. These events can plausibly be associated with the forest clearing observed in 2009 and the following years.

Finally, forest cover loss reached another peak in 2012, which coincides with the conversion of 800 ha of forest to oil palm close to Naranjal by the Malaysian group Melka and awards amounting to US\$570 each to 250 farmers for oil palm production in the framework of the national competitiveness program (AGROIDEAS).
According to a key regional government informant, paying incentives for oil palm production is a social support policy aimed at including smallholders in the market. However, given expanding opportunities, both small and large companies alike were acquiring land. Furthermore, the government has been selling land classified as poorly preserved forest under the condition that forest cover is maintained on $30 \%$ of the land. A brief overview of oil palm cultivation in Ucayali is provided in Supplementary material S3.
Fig. 3 Community-level loss of forest cover between 2001 and 2015 in Ucayali, Peru. a Cumulative forest loss per community. b Forest loss per community per year

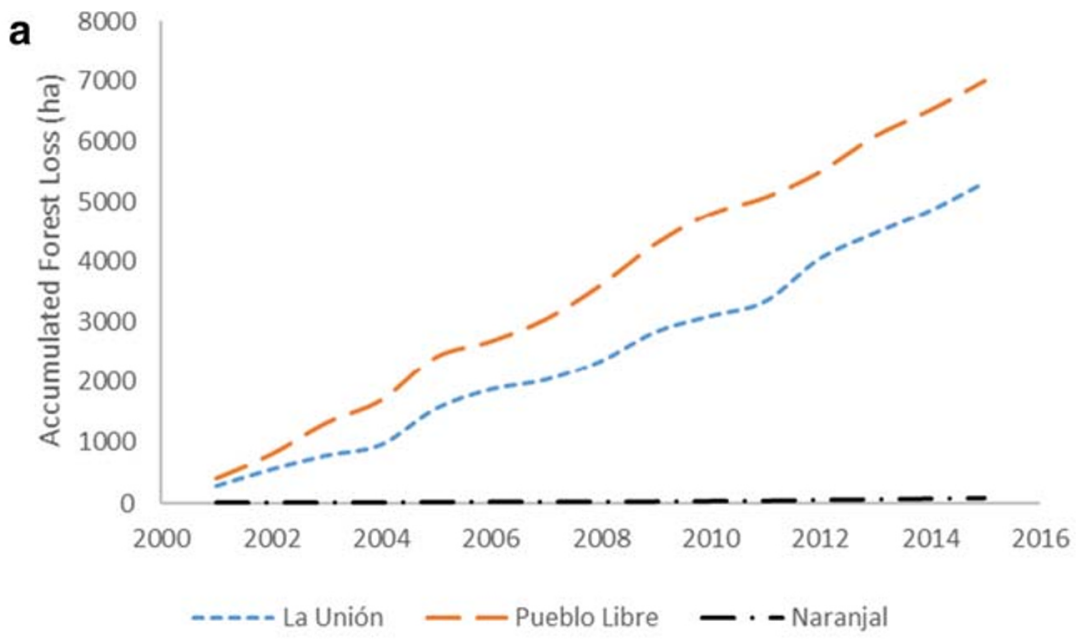

b

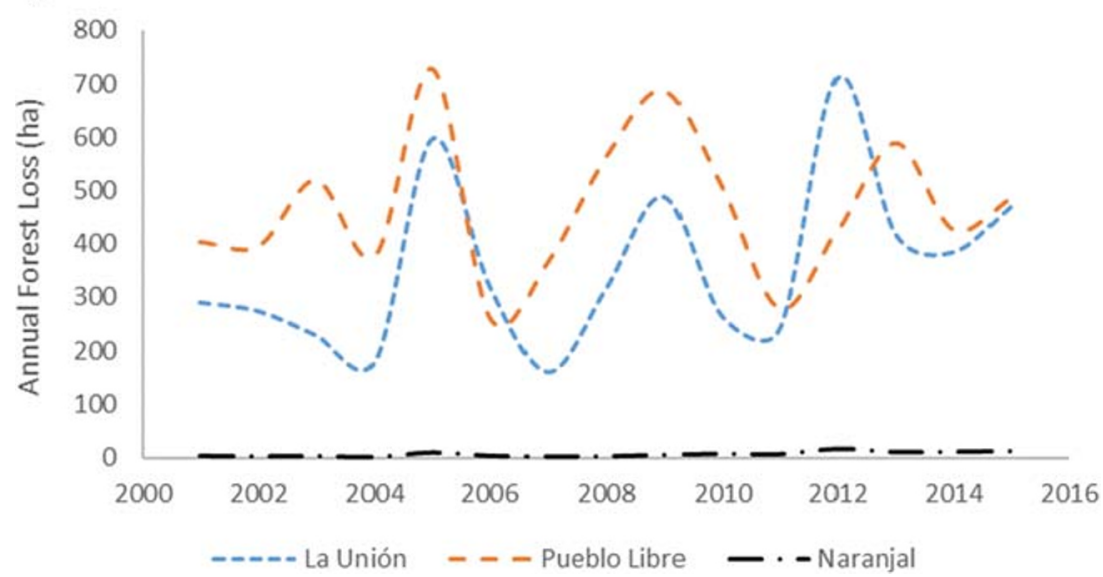




\subsection{Household level changes in socio-economic characteristics, land use and agrobiodiversity}

Table 3 lists the descriptive statistics which characterised households in 2000 and in 2015. In 43 households out of 53, the household head has remained the same. However, at least one household member had migrated in $74 \%$ of the households re-interviewed, compared with $30 \%$ of households in 2000 . The mean age difference reflects individuals' ageing, as expected. Surprisingly, the reported years of education of the household head were slightly lower in 2015 , although that is plausibly due to recall errors linked to the length of the recall period.

The household head mainly worked on the farm $(80 \%$ in $2000,90 \%$ in 2015). Yet the total number of adults dedicated to farming decreased, possibly linked to the ageing of household members and emigration of some family members of working age. At the same time, the number of sources of income slightly increased, possibly linked to more family members starting to work off-farm.

The average total land area owned by households did not change significantly, although there is significant variability especially in Pueblo Libre and La Union. Cultivated area increased almost threefold in Pueblo Libre, where land under oil palm area doubled (Table 4). Conversely, in La Unión, some households acquired new areas of mature and successional forest, but overall the areas dedicated to pasture decreased. In Naranjal, the recent distribution of 10 ha of mature forest per family (Supplementary material S3), explains the strong increase in forest area.

The number of cultivated crops almost halved, from an average of seven crops cultivated by households, to four crops. The number of households who raise livestock has also decreased significantly. Relatively fewer households bred cattle in 2015 than in 2000, but those who did owned significantly more cattle on average. Some households in La Unión and Pueblo Libre started fish farming.

Households who collected wild plants dropped from $54 \%$ to $28 \%$, and wild fruits from $39 \%$ to $11 \%$. In $2000,51 \%$ of the households hunted at least one type of wild animal, compared with $28 \%$ in 2015 . Small local mammals, frequently hunted in 2000, were rarely hunted in 2015 (see Table 6).

Cash crop production increased significantly over the 15 year period: oil palm was cultivated by $36 \%$ of households in 2000 and by $55 \%$ in 2015, cacao production increased from

Table 3 Main differences in socio-economic characteristics and use of agrobiodiversity

\begin{tabular}{|c|c|c|c|c|c|c|c|}
\hline \multirow[t]{2}{*}{ Continuous variables } & \multicolumn{3}{|c|}{2000} & \multicolumn{3}{|c|}{2015} & \multirow[t]{2}{*}{ Wilcoxon test for paired data } \\
\hline & $\mathrm{n}$ & Mean & Std. dev. & $\mathrm{n}$ & Mean & Std. dev. & \\
\hline Years of education of head of household & 53 & 6.08 & 3.63 & 53 & 4.79 & 2.06 & $1.96^{* *}$ \\
\hline Age of head of household & 53 & 41.28 & 9.88 & 53 & 57.34 & 8.94 & $-6.35 * * *$ \\
\hline Age of household members & 53 & 24.05 & 10.95 & 53 & 36.29 & 12.71 & $-5.60 * * *$ \\
\hline Household size & 53 & 5.08 & 1.90 & 53 & 4.51 & 2.58 & $1.91 *$ \\
\hline Dependency ratio & 53 & 0.99 & 0.69 & 50 & 0.63 & 0.61 & $3.08 * * *$ \\
\hline Household members under 18 & 53 & 2.40 & 1.62 & 53 & 1.7 & 1.7 & $2.79 * * *$ \\
\hline Number of members who work on-farm (18 and above) & 53 & 3.66 & 1.89 & 53 & 2.21 & 1.57 & $-4.13 * * *$ \\
\hline Number of income sources & 53 & 1.68 & 0.98 & 53 & 2.39 & 1.39 & $-2.40 * *$ \\
\hline Total land area & 53 & 33.68 & 23.27 & 52 & 33.09 & 28.42 & 0.31 \\
\hline Cultivated area & 53 & 3.08 & 3.22 & 53 & 8.47 & 6.95 & $-5.44 * * *$ \\
\hline Number of livestock (type) & 53 & 2.00 & 0.90 & 53 & 1.55 & 1.07 & $2.77 * * *$ \\
\hline Number of crops cultivated & 53 & 6.81 & 3.73 & 53 & 3.79 & 2.85 & $4.42 * * *$ \\
\hline Number of wild fruits collected & 53 & 0.53 & 0.72 & 53 & 0.13 & 0.39 & $3.46^{* * * *}$ \\
\hline Number of wild leaves collected & 53 & 0.60 & 0.60 & 53 & 0.08 & 0.27 & $4.64 * * *$ \\
\hline Number of wild animals hunted & 53 & 1.64 & 2.22 & 53 & 0.57 & 1.17 & $2.85 * * *$ \\
\hline Categorical variables & $\mathrm{n}$ & $\%$ & & $\mathrm{n}$ & $\%$ & & Pearson chi-squared test \\
\hline Own a television & 21 & $40 \%$ & & 39 & $73 \%$ & & $2.63 *$ \\
\hline Own a refrigerator & 2 & $4 \%$ & & 21 & $40 \%$ & & $3.16^{*}$ \\
\hline Household head works on-farm & 45 & $80 \%$ & & 46 & $90 \%$ & & 1.14 \\
\hline Households who gather wild leaves (\%) & 29 & $54 \%$ & & 15 & $28 \%$ & & 1.82 \\
\hline Households who collect wild fruits (\%) & 21 & $39 \%$ & & 6 & $11 \%$ & & 0.30 \\
\hline Households who hunt animals (\%) & 27 & $51 \%$ & & 15 & $28 \%$ & & 0.68 \\
\hline Households who extract wood (\%) & 26 & $49 \%$ & & 7 & $13 \%$ & & 1,62 \\
\hline
\end{tabular}

$* p=0.1 * * p=0.05 * * * p=0.01$ 
Table 4 Average changes in land use area per household

\begin{tabular}{|c|c|c|c|c|c|c|c|c|c|c|c|c|}
\hline \multirow[t]{3}{*}{ Area } & \multicolumn{4}{|l|}{ La Unión } & \multicolumn{4}{|c|}{ Pueblo Libre } & \multicolumn{4}{|l|}{ Naranjal } \\
\hline & \multicolumn{2}{|l|}{2000 (ha) } & \multicolumn{2}{|l|}{2015 (ha) } & \multicolumn{2}{|l|}{2000 (ha) } & \multicolumn{2}{|l|}{2015 (ha) } & \multicolumn{2}{|l|}{2000 (ha) } & \multicolumn{2}{|l|}{2015 (ha) } \\
\hline & $\begin{array}{l}\text { Median } \\
\text { (mean) }\end{array}$ & IQR & $\begin{array}{l}\text { Median } \\
\text { (mean) }\end{array}$ & IQR & $\begin{array}{l}\text { Median } \\
\text { (mean) }\end{array}$ & IQR & $\begin{array}{l}\text { Median } \\
\text { (mean) }\end{array}$ & IQR & $\begin{array}{l}\text { Median } \\
\text { (mean) }\end{array}$ & IQR & $\begin{array}{l}\text { Median } \\
\text { (mean) }\end{array}$ & IQR \\
\hline Total area & $33(40.2)$ & 37 & $37.5(40.5)$ & 53 & $38.5(38.2)$ & 4 & $35.5(37.5)$ & 22 & $5.75(10.5)$ & 13 & $10.5(12.5)$ & 11 \\
\hline Mature forest & $0(0.8)$ & 0 & $0(2.7)$ & 0 & $5(12.2)$ & 25 & 16.30 & 20 & $0(2.30)$ & 2 & $8.5(7.2)$ & 9.8 \\
\hline $\begin{array}{l}\text { Successional } \\
\text { forest }\end{array}$ & $7(8.2)$ & 11 & $1(10)$ & 14 & $2.5(7.5)$ & 14 & $1.5(4.2)$ & 6.2 & $2.2(3.2)$ & 4 & $2(5.5)$ & 5.5 \\
\hline Cultivated area & $2(2.2)$ & 2 & $4(4.7)$ & 6.5 & $5(4.8)$ & 6.7 & $14.7(14.6)$ & 8.2 & $1(1.2)$ & 2 & $2.5(2.9)$ & 2 \\
\hline Pasture area & $15.2(22.4)$ & 24. & $7(16.8)$ & 23 & $0(0.2)$ & 0.6 & $0.8(0.9)$ & 1.9 & 0.0 & 0.0 & 0.0 & 0.0 \\
\hline
\end{tabular}

$4 \%$ to $36 \%$ of households, while pastureland decreased significantly (Table 5).

\subsection{Households' reasons for land use change}

In the second round of the survey in 2015, we asked farmers who had reported a change in land use open-ended questions about why they made this change. Households mentioned up to three changes over the 15 years.

Farmers who changed the extent of their area under forest, mainly felled the trees to make way for crops, mostly oil palm (Supplementary material S4 shows the different combinations of changes reported by the respondents). Income generation potential and support in the form of government incentives led several households to increase the area they devoted to oil palm cultivation. Some farmers mentioned the availability of family labour as a reason for increasing their cultivated area.

Similarly, areas previously planted with maize were replanted with oil palm or became pastureland. When farmers continued to grow maize, they said it was mainly for selfconsumption.

Interestingly, for many farmers, the shift towards oil palm and cacao was the second change they made in the past 15 years. The first change was often clearing forest or maize area, followed by planting oil palm or cacao on the newly

Table 5 Cash crops and pasture cultivated per household

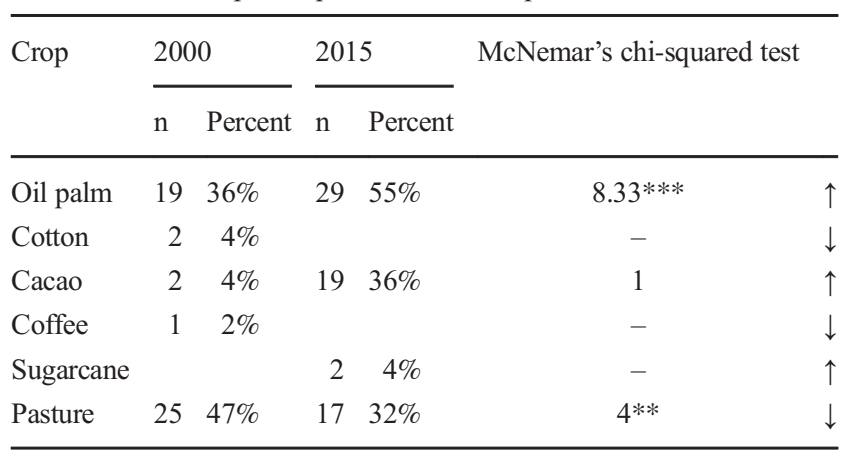

$* p=0.1 * * p=0.05 * * * p=0.01$ available land. Several farmers who already cultivated oil palm in 2000 increased their land under oil palm at least once and sometimes twice in the following 15 years.

These additional changes appear to be linked to waves of public incentives, particularly in 2004 and in 2008. The analysis of maps of forest cover loss corroborates this hypothesis: the highest forest loss peaks occurred in 2005, 2009 and 2012 (see Fig. 2).

\subsection{Household-level changes in food access and in sources of food}

The number of food items cultivated by households decreased significantly between 2000 and 2015, especially vegetables and fruits (Table 6). For example, the native fruit shimbillo (Inga sp.), which was previously cultivated by many households, was not even mentioned in 2015. Cereal production, especially rice, decreased dramatically, as did cassava production. In 2000, households reported growing nine different vegetables in agricultural fields or home gardens, including tomatoes, cucumber, white cabbage, and chillies. In 2015, surveyed households only reported cucumber, chillies, and caigua (Cyclanthera pedata). As shown in Table 4, over the 15-year study period, commercial crops replaced the diversity of crops households previously cultivated for both consumption and sale (the number of cultivated crops was halved), and forest goods.

In terms of dietary changes, a reduction in the household dietary diversity score (HDDS) of 1.3 food groups compared to 2000 reflects a statistically significant decrease in the HDDS (Table 7). The variety of food items consumed also decreased from 69 food items mentioned in 2000 to 35 in 2015.

On the one hand, the consumption of food groups high in animal-protein content increased: especially meat (which increased from $45 \%$ to $58 \%$ of households), eggs (from $30 \%$ to $49 \%$ ), dairy products (from $21 \%$ to $32 \%$ ), and oils and fats (from $77 \%$ to $85 \%$ ). The consumption of roots and tubers 
Table 6 Food items from home grown crop and livestock production, gathering, and hunting in 2000 and 2015, organised in food groups

\begin{tabular}{|c|c|c|c|c|}
\hline Food group & $\begin{array}{l}\text { Item } \\
\text { Local name (Scientific name } ¥)\end{array}$ & $\begin{array}{l}2000 \\
\%(\mathrm{n})\end{array}$ & $\begin{array}{l}2015 \\
\%(\mathrm{n})\end{array}$ & $\begin{array}{l}\text { Mc Nemar's } \\
\text { chi-square test }\end{array}$ \\
\hline \multirow[t]{2}{*}{ Cereals } & Rice & $98(52)$ & $8(4)$ & $48.00 * * *$ \\
\hline & Maize & $74(39)$ & $28(16)$ & $21.16^{* * *}$ \\
\hline White roots and tubers & Cassava & $79(42)$ & $55(29)$ & $8.89 * * *$ \\
\hline \multirow[t]{9}{*}{ Vegetables } & Tomato & $21(11)$ & $15(8)$ & 0.60 \\
\hline & Cucumber & $17(9)$ & $6(3)$ & $3.60^{*}$ \\
\hline & Chillies & $11(6)$ & $2(1)$ & $3.57 *$ \\
\hline & White cabbage & $11(6)$ & 0 & - \\
\hline & Coriander & $9(5)$ & 0 & - \\
\hline & Onion & $8(4)$ & 0 & - \\
\hline & Caigua (Rollinia mисоsa (Jacq.) Baill.) & $6(3)$ & 0 & - \\
\hline & Chinese cabbage & $4(2)$ & 0 & - \\
\hline & Lettuce & $2(1)$ & 0 & - \\
\hline \multirow[t]{33}{*}{ Fruits } & Banana & $70(37)$ & $66(35)$ & 0.25 \\
\hline & Orange & $49(26)$ & $19(10)$ & $16^{* * *}$ \\
\hline & Lemon & $47(25)$ & $17(9)$ & $9.14 * * *$ \\
\hline & Mango & $36(19)$ & $8(4)$ & $10.71 * * *$ \\
\hline & Shebon (Attalea butyracea) & $35(19)$ & $2(1)$ & $16.20 * * *$ \\
\hline & Shimbillo (Inga sp.) & $23(4)$ & 0 & - \\
\hline & Shapaja (Schleea cephalotes) & $19(10)$ & $6(3)$ & $5.44 * *$ \\
\hline & Avocado & $15(8)$ & $2(1)$ & $5.44 * *$ \\
\hline & Ungurahui (Oenocarpus bataua Mart.) & $15(8)$ & $8(4)$ & 5.44 \\
\hline & Pijuayo (Bactris gasipaes Kunth) & $13(7)$ & $2(1)$ & $4.50 * *$ \\
\hline & Pineapple & $11(6)$ & $8(4)$ & 0.40 \\
\hline & Umari (Poraqueiba sericea Tul.) & $11(6)$ & $2(1)$ & $5.00 * *$ \\
\hline & Carambola (Averrhoa carambola L.) & $8(4)$ & 0 & - \\
\hline & Coconut & $8(4)$ & $11(6)$ & 0.50 \\
\hline & Guaba (Inga edulis Mart.) & $8(4)$ & $9(5)$ & 0.14 \\
\hline & Pomarosa (Syzygium malaccense (L.) Merr. \& L.M.Perry) & $8(4)$ & $2(1)$ & 1.80 \\
\hline & Zapote (Matisia cordata Humb. \& Bonpl.) & $8(4)$ & $6(3)$ & 0.33 \\
\hline & Aguaje (Mauritia flexuosa L.f.) & $8(4)$ & $4(2)$ & 0.67 \\
\hline & Mandarine & $6(3)$ & $4(2)$ & 0.20 \\
\hline & Papaya & $6(3)$ & $4(2)$ & 0.33 \\
\hline & Taperiba (Spondias dulcis Parkinson) & $6(3)$ & 0 & - \\
\hline & Anona (Rollinia mucosa (Jacq.) Baill.) & $4(2)$ & 0 & - \\
\hline & Watermelon & $4(2)$ & $2(1)$ & 0.33 \\
\hline & Grapefruit & $4(2)$ & $6(3)$ & 0.20 \\
\hline & Cocona (Solanum sessiliflorum var. sessiliflorum Dunal) & $4(2)$ & 0 & - \\
\hline & Huito (Genipa Americana) & $4(2)$ & 0 & - \\
\hline & Guayaba & $4(2)$ & $2(1)$ & 0.33 \\
\hline & Caimito (Pouteria caimito (Ruiz \& Pav.) Radlk.) & $2(1)$ & $6(3)$ & 2.00 \\
\hline & Сати сати (Myrciaria dubia (Kunth) Mc Vaugh.) & $2(1)$ & 0 & - \\
\hline & Copoazú (Theobroma grandiflorum (Willd. ex Spreng.) K.Schum.) & $2(1)$ & 0 & - \\
\hline & Dale dale (Calathea allouia (Aubl.) Lind.) & $2(1)$ & 0 & - \\
\hline & Granadilla (Passiflora acuminata DC.) & $2(1)$ & 0 & - \\
\hline & Uvilla (Pourouma cecropiifolia Mart.) & 0 & $2(1)$ & - \\
\hline \multirow[t]{3}{*}{ Meats } & Poultry & $100(53)$ & $89(47)$ & $6.00 * *$ \\
\hline & Calves, cows and bulls & $36(19)$ & $26(14)$ & 1.92 \\
\hline & Pigs & $58(31)$ & $11(6)$ & $23.15^{* * *}$ \\
\hline
\end{tabular}


Table 6 (continued)

\begin{tabular}{|c|c|c|c|c|c|}
\hline Food group & $\begin{array}{l}\text { Item } \\
\text { Local name (Scientific name } ¥)\end{array}$ & $\begin{array}{l}2000 \\
\%(\mathrm{n})\end{array}$ & $\begin{array}{l}2015 \\
\%(\mathrm{n})\end{array}$ & $\begin{array}{l}\text { Mc Nemar's } \\
\text { chi-square test }\end{array}$ & \\
\hline \multirow{25}{*}{ Bushmeats } & Ducks & $38(20)$ & $28(15)$ & 1.32 & \\
\hline & Sheep & $23(12)$ & $6(3)$ & $5.40 * *$ & \\
\hline & Guinea pigs (cuy) & $15(8)$ & $6(3)$ & $3.57 *$ & \\
\hline & Turkeys & $4(2)$ & $6(3)$ & 0.20 & \\
\hline & Añuje (Dasyprocta fuliginosa (Wagler, 1832)) & $30(16)$ & $9(5)$ & 7.12 & \\
\hline & Majaz (Tayassu peccari (Link, 1795)) & $26(14)$ & $11(6)$ & $4 * *$ & \\
\hline & Carachupa (Dasypus novemcinctus (Linnaeus, 1758)) & $23(12)$ & $17(9)$ & 0.69 & \\
\hline & Sajino (Tayassu tajacu (Linnaeus, 1758)) & $17(9)$ & $4(2)$ & $4.45 * *$ & \\
\hline & Pucacunga (Penelope jacquacu (Spix, 1825)) & $13(7)$ & $2(1)$ & $4.5 * *$ & \\
\hline & Mono negro (Sapajus apella (Linnaeus, 1758)) & $11(6)$ & $2(1)$ & $3.57 *$ & \\
\hline & Perdiz (Crypturellus soui ((Hermann, 1783)) & $9(5)$ & 0 & - & \\
\hline & Manacaraco (Ortalis guttata (Spix, 1825)) & $6(3)$ & $2(1)$ & 1 & \\
\hline & Huangana (Tayassu peccari (Link, 1795)) & $6(3)$ & 0 & - & \\
\hline & Unchala (Aramides cajanea (Statius Muller, 1776)) & $4(2)$ & 0 & - & \\
\hline & Ronsoco (Hydrochoerus hydrochaeris (Linnaeus, 1766)) & $2(1)$ & $2(1)$ & 1 & \\
\hline & Venado (Mazama americana (Erxleben, 1777)) & $2(1)$ & 0 & - & \\
\hline & Chosna (kinkajou) (Dasypus novemcinctus (Linnaeus, 1758)) & $2(1)$ & 0 & - & \\
\hline & Ardilla (Sciuridae) & $2(1)$ & 0 & - & \\
\hline & Paujil (Crax globulosa (Spix, 1825)) & $2(1)$ & 0 & - & \\
\hline & Torcaza (Columbidae) & $2(1)$ & 0 & - & \\
\hline & Gavilán (Accipitridae) & $2(1)$ & 0 & - & \\
\hline & Paloma (Columbidae) & $2(1)$ & 0 & - & \\
\hline & Pato silvestre (Anatidae) & 0 & $2(1)$ & - & \\
\hline & Motelo (Geochelone denticulata (Linnaeus, 1766)) & 0 & $2(1)$ & - & \\
\hline & Sachapato (Cairina moschata) & 0 & $2(1)$ & - & \\
\hline Eggs & Chicken eggs & $19(10)$ & $28(4)$ & $3^{*}$ & \\
\hline Fish and seafood & Fish (from fish farms) & 0 & $17(9)$ & - & \\
\hline \multirow[t]{3}{*}{ Legumes, nuts, and seeds } & Beans & $23(12)$ & $4(2)$ & $8.3 * * *$ & \\
\hline & Casho & $4(2)$ & 0 & - & \\
\hline & Groundnuts & 0 & $2(1)$ & - & \\
\hline Milk and milk products & Milk & $17(11)$ & $21(6)$ & 2.27 & \\
\hline \multirow[t]{4}{*}{ Spices, condiments, beverages } & Hierba luisa (Cymbopagon citratus (DC.) Stapf) & $6(3)$ & 0 & - & \\
\hline & Pepper & $4(2)$ & 0 & - & $\downarrow$ \\
\hline & Achiote (Bixa orellana L.) & $2(1)$ & 0 & - & $\downarrow$ \\
\hline & Guisador (Curcuma longa L.) & $2(1)$ & 0 & - & \\
\hline
\end{tabular}

$¥$ Only provided when no English name is available

$* p=0.1 * * p=0.05 * * * p=0.01$

Table 7 Household dietary diversity score (HDDS) in Ucayali, Peru

\begin{tabular}{lllllll}
\hline Variable & 2000 & & & \multicolumn{2}{c}{2015} & \multirow{2}{*}{ Wilcoxon signed-rank test } \\
\cline { 2 - 3 } & $\mathrm{N}$ & Mean (S.D.) & & $\mathrm{n}$ & Mean (S.D.) & \\
\hline HDDS & 49 & $7.87(1.70)$ & & 51 & $6.5(1.47)$ & $3.48^{* * * *}$ \\
HDDS La Unión & 21 & $8.33(1.59)$ & & 21 & $6.71(1.15)$ & $2.71^{* * *}$ \\
HDDS Naranjal & 10 & $6.4(1.5)$ & & 10 & $6(2.05)$ & 0.53 \\
HDDS Pueblo Libre & 18 & $8.16(1.54)$ & & 20 & $6.55(1.46)$ & $2.35^{* *}$ \\
\hline
\end{tabular}

$* p=0.1 * * p=0.05 * * * p=0.01$ 
decreased remarkably (from $66 \%$ to $28 \%$ of households), as did the consumption of fruits (from $79 \%$ to $68 \%$ ) and sweet processed food items (from $72 \%$ to $57 \%$ ).

In parallel with their reduced production, in 2015 households tended to purchase cereals in the market. The HDDS score based on the farm's own production was significantly lower than in 2000, while the score based on purchased food was almost two points higher.

In terms of food items, cassava, tomato, banana, bean, and potato consumption decreased by $88 \%, 50 \%, 29 \%, 23 \%$, and $19 \%$, respectively, reflecting a decrease in the cultivation of these crops. Conversely, the consumption of products such as coffee, bread and chicken more than doubled (by $180 \%$, $138 \%$, and $115 \%$, respectively), and households consumed more oats, eggs, and milk (canned) $(75 \%, 63 \%$, and $55 \%$, respectively).

Disaggregated by community, La Unión and Pueblo Libre, which are characterised by more commercial agriculture, accounted for the biggest decrease in food access. In parallel, the number of crops grown in these communities decreased significantly: from 6.4 to 2.7 in La Unión, and from 6.7 to 3.6 in Pueblo Libre. By contrast, there was no significant change in food access over time in the riverine community of Naranjal. This community presented significantly higher agricultural biodiversity than the roadside communities. In addition, while diets in La Unión and Pueblo Libre were more diverse than in Naranjal in 2000, the overall score for the three communities in 2015 was similar, with 6.5 food groups on average. Variability and maximum scores for the household dietary diversity score were therefore higher in 2000 than in 2015.

In 2000 , the food and drinks consumed over the $24 \mathrm{~h}$ preceding the survey came from more diversified sources than in 2015 (Fig. 4). Back then, 92\% of households consumed at least one purchased food item, $85 \%$ consumed crops and animals they produced themselves, and $11 \%$ ate a food item gathered, hunted, or fished.

In 2015, however, the foods consumed during the 24-h period preceding the survey were either purchased in the market or produced on the farm. About $44 \%$ of households ate only food purchased in the market, while in 2000 just three households only consumed purchased food the day preceding the survey.

The biggest change in sources of food was in Pueblo Libre, where $73 \%$ of households consumed food produced on their land in 2000, and only $23 \%$ in 2015 . Conversely, almost all households in the riverine community of Naranjal still consumed food they produced themselves.

\subsection{Linking changes in livelihoods, land use, agrobiodiversity and food access}

Cluster analysis revealed four clusters in both 2000 and 2015, but with different food consumption patterns and livelihood strategies. Supplementary material S5 and S6 present the results of the hierarchical clustering analysis in graphic form and the descriptive statistics per cluster and per year. The clusters are described from the highest to the lowest household dietary diversity score.

We can characterise the four clusters in 2000 as: 1) small livestock owners; 2) diversified medium holders; 3) diversified large holders: 4) "young rice producers".

The cluster "small livestock owners" grouped 17 households in La Unión whose livelihoods depended on livestock, especially pigs and sheep, with large natural pastures and successional forests. They were more likely to produce fruits and tubers than households in the other clusters. Households in this cluster appeared to be better off in terms of household assets and food access in 2000. They presented the highest HDDS (8.6 food groups on average).

The cluster "diversified large holders" grouped 13 households in Pueblo Libre (all growing oil palm) and one household in Naranjal (who did not grow oil palm). These are relatively younger households who owned the largest cultivated areas and mature forests. They owned cattle and had the highest crop diversity after "diversified slash and burn farmers". At the same time, they had the second highest HDDS (8.4 food groups on average).
Fig. 4 Sources of foods consumed in the $24 \mathrm{~h}$ preceding the survey

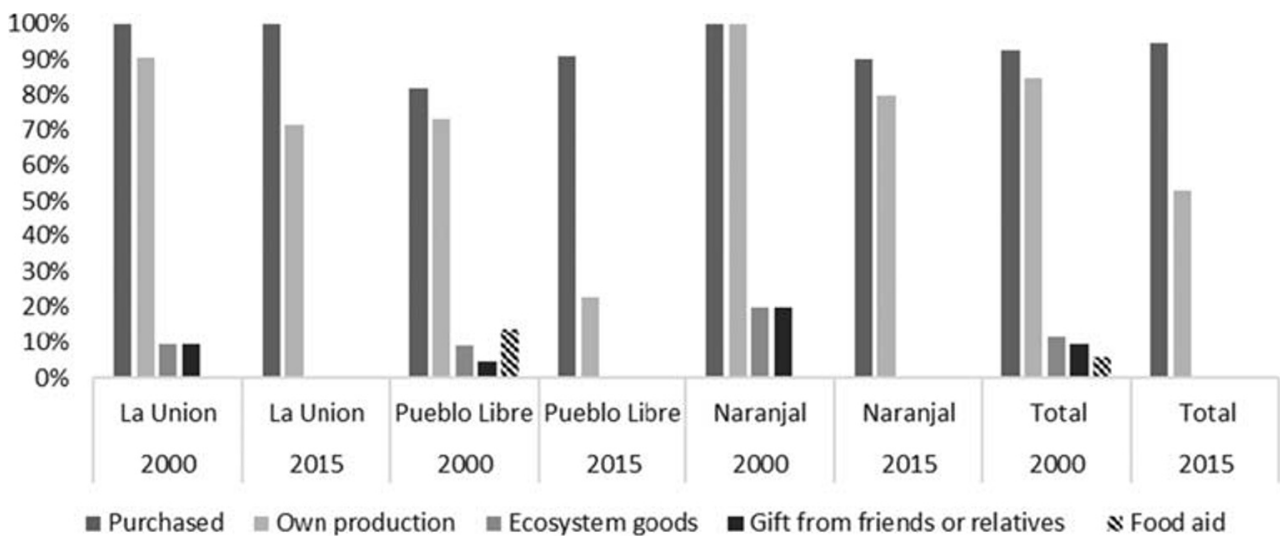


The cluster "young rice producers", which grouped four households in Pueblo Libre and one in Naranjal, did not cultivate oil palm (except one), but focused on selling rice and pigs. They had no off-farm sources of income and possessed no basic household appliances. However, they had large areas under mature and successional forest. They were the youngest households and had the highest level of education. They had the second lowest HDDS ( 7.8 food groups on average).

The cluster "diversified medium holders" grouped eight households in Naranjal and three in La Unión. These were older households, with an average age difference of ten years compared to the young colonists in Pueblo Libre. They cultivated small areas and maintained small to medium successional forests but presented the highest crop diversity among all the clusters in 2000. They consumed fewer foods with high protein and fat contents, but more fruits, vegetables, and tubers. Despite high crop diversity, they had the lowest HDDS in 2000 (six food groups on average).

The clusters in 2015 show that, although food consumption patterns and livelihood strategies changed, the four clusters reveal a trend towards agricultural specialisation in which location played an important role through a sort of "path dependency". This specialisation appears to be linked to the starting point: households who focused on livestock in 2000 , tended to specialise in livestock; those who had started to plant oil palm, specialised in oil palm; those who added large mature forest or successional forest areas for new plantations, tended to plant oil palm. We consequently identified four main clusters: 1 ) cattle ranchers; 2) oil palm growers; 3) specialised cash crop growers; 4) diversified cacao growers.

The cluster "cattle ranchers" grouped 11 households in La Unión, two in Pueblo Libre and one in Naranjal, with large cattle pastures and successional forest. Milk and meat consumption were higher in these cattle-raising households. Half the families owned relatively expensive household appliances such as stoves and refrigerators. They had lower crop diversity ( 4.5 crops grown on average) and mainly grew fruits, together with some tubers and vegetables. They had the highest HDDS (7.3 food groups on average), although lower than in 2000, with a full food group less.

The cluster "diversified cacao growers", grouped households in Naranjal. Although their crop diversity decreased compared to 2000, it was still the highest (an average of six crops grown). Interestingly, all households except one cultivated cacao in 2015, compared with none in 2000. Most households still practiced hunting. Their meat and fat consumption increased compared to 2000. Their HDDS was higher than in 2000 but converged to the same level as in the other clusters in 2015 (6.6 food groups on average).

The cluster "oil palm growers" grouped seven households in Pueblo Libre and one in La Unión similar to those in the "oil palm growers" cluster in 2000. They had large cultivated areas and mature forests, and all cultivated oil palm. This cluster had the second lowest crop diversity score (an average of 4.6 crops grown). Despite growing a cash crop, some of them diversified their income sources by working as daily labourers in other fields or as wage labour. Their HDDS was on average 6.4 food groups.

The cluster "specialised cash crop growers" grouped 11 households in Pueblo Libre, seven in La Unión and one in Naranjal: respectively, they grew oil palm and cacao on large areas, but also owned large areas of forest. Most owned a refrigerator, stove, and television. Interestingly, they had the lowest crop diversity (an average of 2.7 crops grown) and the lowest HDDS (an average of 6.2 food groups), despite being better off in terms of household assets and having large forest areas that could provide a variety of foods.

\section{Discussion}

Our longitudinal analysis in mestizo communities in the Peruvian Amazon revealed that, in a period of 15 years, the expansion of commercial agriculture at the forest frontier appears to be associated with simplification of food production systems, reduced agricultural diversity and less access to food, measured in terms of the household dietary diversity score. In the original 2000 study, participating communities were selected to represent the main land use systems and livelihood strategies in Ucayali, among which we focus on mestizo families. Despite the small sample size, our case study adequately characterises the main land use systems and livelihood strategies in the Peruvian Amazon compared with recent literature (Bennett et al. 2018; Francesconi et al. 2018), and provides valuable insights into emerging trends.

As mestizo households in the three sites we studied shifted to market-orientated production and crop specialisation, their dependency on markets for household consumption increased, while the diversity of food sources decreased. Conversely, a review of the links between agricultural biodiversity, dietary diversity and nutritional status, found that the diets of households with partly market-orientated farms are more diverse than the diets of less market-orientated farms (Jones 2017). However, in the communities we studied, the increase in agricultural income over time was not reflected in increased access to food. Multiple factors certainly affect how the additional income will be invested (e.g., whether roads and transport infrastructure are available, the types of food items available in the market, changes in cultural preferences, gender aspects of intra-household decision making). At the same time, we found that income from oil palm and cacao, and more market orientated agricultural production, are associated with increased asset ownership in 2015. In 2000, the mestizo communities surveyed used diverse livelihood strategies depending on the surrounding ecosystems, including raising livestock, growing crops, and using forest 
goods. In 2015, fewer households hunted, fished, gathered and collected forest/river products, or cultivated local crops and trees. Francesconi et al. (2018) obtained similar results for hunting. Porro et al. (2014) reported that Ucayali households are highly dependent on agriculture, even though forest products still play a role.

Although the average land area did not change significantly, cultivated areas increased almost threefold. This expansion was often at the expense of forest areas, which appeared to be kept more as reserve land for new crops than for active use (Andrieu et al. 2019). In our study context, the acquisition of property rights is based on demonstrating the land is actually used, which also encourages deforestation. The higher oil palm yields obtained from plantations planted after forest clearing also encourage deforestation. This specialisation in cash crops has been encouraged by national and regional policies and access to credit, already linked to deforestation (Arce-Nazario 2007).

Interestingly, between 2001 and 2012, deforestation appeared to be driven by smallholders opening up new land or extending existing area to cultivate cash crops, whereas the peaks that occurred in 2012-2013 appeared to be caused by extensive land clearing by a private company. Farmers with more agrobiodiversity appear to be less likely to clear forest, and more likely to be food secure (Andrieu et al. 2019). Certainly, deforestation can have detrimental effects on local food security (Arnold et al. 2011). In fact, not only the reduced number of food crops and livestock, but also the decline in gathering, hunting, and fishing to obtain wild foods is alarming given their role in dietary and nutritional diversity (Bharucha and Pretty 2015). For instance, it has been reported that wild food plants are important for building food resilience needed for the lean months and for periods of scarcity, particularly for the poorest and most vulnerable households (CruzGarcia and Price 2014; Grivetti and Ogle 2000). This is critical in a region like Ucayali, where chronic malnutrition decreased between 2010 and 2016, but still affects $21 \%$ of children (Hernández-Vásquez and Tapia-López 2017). At the same time, overweight and obesity are increasing slightly in the Ucayali region (Ministerio de Salud 2014).

As we have shown, the household dietary diversity score, a measure of food access, decreased in the study period, mirroring the decline of crop diversity in agricultural fields and the reduced use of ecosystem goods from forests. Communities which are more orientated toward commercial agriculture accounted for the biggest decrease in food access. With the increased market orientation of agricultural production, the consumption of animal protein and fat increased, as also reported in other studies at the forest frontier in Peru, Colombia and Brazil (Piperata et al. 2011; Useche and Twyman 2016; Van Vliet et al. 2012), and reported as a major trend worldwide (Khoury et al. 2014). Ambikapathi et al. (2018) found that, in the Peruvian Amazon, sugary items, animal source food and fat intake are positively associated, as our results partially suggest. These results are extremely important, given that there is a general trend in the food and agricultural sciences to assume that increased income implies improved food security (Cruz-Garcia et al. 2016), whereas our results revealed exactly the opposite trend concerning food access.

Our results help answer a long-standing research question concerning the extent to which agricultural expansion (and commercial agricultural production) ensures food security (Pinstrup-Andersen 2013), showing that, on the contrary, it may increase local food insecurity, at least in terms of access to diverse foods. Loss of local agricultural diversity has been linked to increased specialisation and homogenisation of agricultural systems (McKenzie and Williams 2015). As we have shown, homogenisation toward commercial crops with lower agricultural diversity parallels homogenisation of diets, with a shift towards higher animal protein and fat content combined with less diverse access to food. The changes we found might be unhealthy as they point towards diets higher in saturated fats, sodium, and ultra-processed foods (Popkin and Reardon 2018). This is alarming since a marked rise in obesity in rural areas in Peru has been reported (Bixby et al. 2019), reflecting a worldwide trend. The reduction in the number of food groups consumed (i.e. roots, tubers and fruits) and food items consumed is also worrying, as dietary nutrient adequacy is likely to increase with every additional plant or animal species consumed (Lachat et al. 2018). Springmann et al. (2018) further argue that diets with low to moderate amounts of animal-source foods and low red meat and sugar, coupled with high amounts of fruits, vegetables, legumes, and nuts, would reduce environmental impacts, while improving dietary health in selected regions. The results of our study not only have major implications for land use and food policies in the Peruvian Amazon, but also for health policies, since it has recently been highlighted that unhealthy diets are the main cause of disease worldwide (Afshin et al. 2019).

Our results are also consistent with emerging evidence for a dietary transition in the Amazon (Port Lourenço et al. 2008; Van Vliet et al. 2012) from traditional foods to staples and homogenised diets. These results are in line with global trends that point to a convergence in consumption patterns, as diets rely more on a few staple grains and increased protein intake (Khoury et al. 2014). It is certainly important that future development actions at the Amazonian forest-agriculture interface promote agrobiodiversity over the expansion of cash crops to ensure the long-term food and nutrition security of smallholder farmers.

The results of this study demonstrate that analysing the interactions between agricultural production choices and nutrition and health and comparing changes in diets with changes in agricultural biodiversity and production choices enable a fuller understanding of food systems and render 
recommendations for sustainable change feasible. Understanding changes in diets and agricultural biodiversity requires a landscape, multi-temporal and interdisciplinary approach.

\section{Conclusion and policy considerations}

Our study of mestizo farming households in the Ucayali region of Peru points to an emerging dietary transition coupled with loss of forest cover and agricultural biodiversity. We confirmed our starting hypothesis that within broader economic and institutional change, cash crop expansion and farm specialisation are associated with deforestation, reduced agrobiodiversity and changes in human diets. In the 15-year study period, farming households shifted from diets based on limited consumption of meat and dairy items and high consumption of plant-based foods, towards diets with high protein and fat content, with food items increasingly purchased in the market.

In parallel, we found that the production systems became less diversified, more market-orientated and specialised toward commercial crops. The conversion of tropical forest to commercial agriculture, while potentially improving rural income in the short term, may threaten local livelihoods and food access in the long term. We argue that understanding agricultural production choices focusing on interactions with food security, and weighting changes in rural diets with changes in land use, markets and agricultural biodiversity, will enable a fuller understanding of food systems and recommendations for sustainable change. Such studies must account for rapidly changing ecosystems. The implementation of longitudinal studies that account for food and production choices can shed light on these dynamic interactions and inform science-based policy. A landscape and multi-temporal approach is therefore needed to understand these interactions. Moreover, in longitudinal studies, the understanding of how the family life cycle stage affects the results is important. However, we did not add the family life cycle stage of mestizo households as a variable to be assessed, because this was not part of the original study. But we recommend that future studies include such analysis.

At the policy level, agricultural, nutritional and food policies which jointly promote more diverse production systems supporting income generation and/or self-consumption, combined with diverse and nutritional diets, could address the triple burden of malnutrition while reducing pressure on the environment. In this context, focusing on integrated solutions at a landscape scale would enable the identification of farming systems with multidimensional benefits and fewer cultural, social, economic and environmental trade-offs. The extent to which the parallel homogenisation of diets and agricultural production systems could jeopardise food access of households located in highly dynamic landscapes requires specific research and policy development. Future studies on the healthiness of the diet in the Amazon deforestation frontier are needed, including quantitative analysis of the nutritional adequacy, moderation, safety and diversity linked to land use, social and economic change.

Acknowledgments This study was partially funded by the "ASSETS: Attaining Sustainable Services from Ecosystems through Trade-off Scenarios" initiative and the CGIAR Research Programme on Water, Land and Ecosystems (WLE). We would like to thank Tamsyn Murray for providing the data. We are grateful to all those who helped with data collection, in particular, Danica Pisango and Maria Claudia Tristan Febres. We are most grateful to the local communities in Ucayali who took part in the study, for patiently sharing their knowledge and experiences with us.

\section{Compliance with ethical standards}

Ethical approval All procedures performed were in accordance with the ethical standards of the International Center for Tropical Agriculture (CIAT). Free prior informed consent was obtained from all individual participants included in the study.

Conflict of interest The authors declared that they have no conflict of interest.

Open Access This article is licensed under a Creative Commons Attribution 4.0 International License, which permits use, sharing, adaptation, distribution and reproduction in any medium or format, as long as you give appropriate credit to the original author(s) and the source, provide a link to the Creative Commons licence, and indicate if changes were made. The images or other third party material in this article are included in the article's Creative Commons licence, unless indicated otherwise in a credit line to the material. If material is not included in the article's Creative Commons licence and your intended use is not permitted by statutory regulation or exceeds the permitted use, you will need to obtain permission directly from the copyright holder. To view a copy of this licence, visit http://creativecommons.org/licenses/by/4.0/.

\section{References}

Afshin, A., Sur, P. J., Fay, K. A., Cornaby, L., Ferrara, G., Salama, J. S., Mullany, E. C., Abate, K. H., Abbafati, C., Abebe, Z., et al. (2019). Health effects of dietary risks in 195 countries, 1990-2017: A systematic analysis for the global burden of disease study 2017. The Lancet, 393, 1958-1972.

Alderman, H., Behrman, J., Watkins, S., Kohler, H.-P., \& Maluccio, J. A. (2001). Attrition in longitudinal household survey data: Some tests for three developing-country samples. Demographic Research, 5, 79-124.

Alvarez, N. L., \& Naughton-Treves, L. (2003). Linking National Agrarian Policy to deforestation in the Peruvian Amazon: A case study of Tambopata, 1986-1997. Ambio: A Journal of the Human Environment, 32, 269-274.

Amancio, N. (2016). Serfor: Daños ocasionados por empresas vinculadas a Dennis Melka suman US\$ 117 millones [WWW Document]. Ojo Público | Las historias que otros no te quieren contar. URL http://ojopublico.com/307/empresas-vinculadas-dennis-melka-ocasionaronmillonaria-deforestacion-en-la-amazonia (accessed 10.24.17).

Ambikapathi, R., Rothstein, J. D., Yori, P. P., Olortegui, M. P., Lee, G., Kosek, M. N., \& Caulfield, L. E. (2018). Food purchase patterns indicative of household food access insecurity, children's dietary diversity and intake, and nutritional status using a newly developed and validated tool in the Peruvian Amazon. Food Security, 10(4), 999-1011. 
Andersen, L. E., Granger, C. W. J., Reis, E. J., \& Weinhold, D. (2002). The dynamics of deforestation and economic growth in the Brazilian Amazon. Canadian Journal of Agricultural Economics, 52, 211-216.

Andrieu, N., Blundo-Canto, G., \& Cruz-Garcia, G. S. (2019). Trade-offs between food security and forest exploitation by mestizo households in Ucayali, Peruvian Amazon. Agricultural Systems, 173, 64-77.

Arce-Nazario, J. A. (2007). Human landscapes have complex trajectories: Reconstructing Peruvian Amazon landscape history from 1948 to 2005. Landscape Ecology, 22, 89-101.

Armenteras, D., Rudas, G., Rodriguez, N., Sua, S., \& Romero, M. (2006). Patterns and causes of deforestation in the Colombian Amazon. Ecological Indicators, 6, 353-368.

Arnold, M., Powell, B., Shanley, P., \& Sunderland, T. C. H. (2011). EDITORIAL: Forests, biodiversity and food security. International Forestry Review, 13, 259-264.

Arslan, A., \& Taylor, J. E. (2009). Farmers' subjective valuation of subsistence crops: The case of traditional maize in Mexico. American Journal of Agricultural Economics, 91, 956-972.

Babigumira, R., Angelsen, A., Buis, M., Bauch, S., Sunderland, T., \& Wunder, S. (2014). Forest clearing in rural livelihoods: Householdlevel global-comparative evidence. World Development, 64, S67-S79.

Banco Central de Reserva del Perú. (2012). Informe Económico y Social Ucayali, Encuentro Económico. Banco Central de Reserva del Perú (BCRP), Perú. 147 p.

Barber, C. P., Cochrane, M. A., Souza, C. M., \& Laurance, W. F. (2014). Roads, deforestation, and the mitigating effect of protected areas in the Amazon. Biological Conservation, 177, 203-209.

Behera, R. N., Nayak, D. K., Andersen, P., \& Måren, I. E. (2015). From jhum to broom: Agricultural land-use change and food security implications on the Meghalaya plateau, India. Ambio, 63-77.

Bellon, M. R., \& Hellin, J. (2011). Planting hybrids, keeping landraces: Agricultural modernization and tradition among small-scale maize farmers in Chiapas, Mexico. World Development, 39, 1434-1443.

Bellon, M. R., Ntandou-Bouzitou, G. D., \& Caracciolo, F. (2016). Onfarm diversity and market participation are positively associated with dietary diversity of rural mothers in southern Benin, West Africa. PLoS One, 11(9), e0162535.

Bennett, A., Ravikumar, A., \& Cronkleton, P. (2018). The effects of rural development policy on land rights distribution and land use scenarios: The case of oil palm in the Peruvian Amazon. Land Use Policy, 70, 84-93.

Berti, P. R. (2015). Relationship between production diversity and dietary diversity depends on how number of foods is counted. Proceedings of the National Academy of Sciences, 112, E5656-E5656.

Bharucha, Z.P., \& Pretty, J. (2015). Wild foods. The Oxford Handbook of Food, Politics, and Society.

Bixby, H., Bentham, J., Zhou, B., Di Cesare, M., Paciorek, C., Bennett, J., Taddei, C., Stevens, G., Rodriguez-Martinez, A., et al. (2019). Rising rural body-mass index is the main driver of the global obesity epidemic in adults. Nature, 569, 260.

Brush, S. B. (1995). In situ conservation of landraces in centers of crop diversity. Crop Science, 35, 346.

Butler, R. A., \& Laurance, W. F. (2009). Is oil palm the next emerging threat to the Amazon? Tropical Conservation Science, 2, 1-10.

Chappell, M. J., \& LaValle, L. A. (2011). Food security and biodiversity: Can we have both? An agroecological analysis. Agriculture and Human Values, 28, 3-26.

Chavez, A. B., \& Perz, S. G. (2012). Adoption of policy incentives and land use: Lessons from frontier agriculture in southeastern Peru. Human Ecology, 40, 525-539.

Coomes, O. T. (1996). State credit programs and the peasantry under populist regimes: Lessons from the APRA experience in the Peruvian Amazon. World Development, 24, 1333-1346.

Cruz-Garcia, G. S., \& Price, L. L. (2014). Gathering of wild food plants in anthropogenic environments across the seasons: Implications for poor and vulnerable farm households. Ecology of Food and Nutrition, 53, 363-389.

Cruz-Garcia, G.S., \& Vael, L. (2017). El manejo de plantas silvestres alimenticias en escenarios de deforestación, ilustrado por una comunidad mestiza de la Amazonía Peruana, in: Domesticación En El Continente Americano. Casas, A.; Torres-Guevara, J.; Parra, F. (Eds). 575 p. Universidad Nacional Agraria La Molina (UNALM), Lima, pp. 328-344.

Cruz-Garcia, G. S., Sachet, E., Vanegas, M., \& Piispanen, K. (2016). Are the major imperatives of food security missing in ecosystem services research? Ecosystem Services, 19, 19-31.

Cumbicus, A., \& Lopez, M. (2017). Caracterización del departamento de Ucayali. Banco Central de Reserva del Peru. Sucursal Iquitos. 6 p.

Diaz Encinas, A. (2009). Migración y urbanización en la región Ucayali: 1981-2007. Investigaciones Sociales, 13, 117-138.

Dourojeanni, M. J., Barandiarán, A., \& Dourojeanni, D. (Eds.). (2009). Amazonía Peruana en 2021: explotación de recursos naturales e infraestructura: ¿Qué está pasando? ¿Qué es lo que significa pra el futuro?, 1. ed. ed. ProNaturaleza : Fundación Peruana para la Conservación de la Naturaleza, Lima, Perú. 6 p.

ESRI, R. (2011). ArcGIS desktop: release 10. Environmental Systems Research Institute, CA, USA.

Foley, J. A., Asner, G. P., Costa, M. H., Coe, M. T., DeFries, R., Gibbs, H. K., Howard, E. A., Olson, S., Patz, J., Ramankutty, N., \& Snyder, P. (2007). Amazonia revealed: Forest degradation and loss of ecosystem goods and services in the Amazon Basin. Frontiers in Ecology and the Environment, 5, 25-32.

Fort, R., \& Borasino, E. (Eds.). (2016). ¿Agroindustria en la Amazonía? posibilidades para el desarrollo inclusivo y sostenible de la palma aceitera en el Perú. GRADE, Grupo de Análisis para el Desarrollo, Lima, Perú. 228 p.

Francesconi, W., Bax, V., Blundo-Canto, G., Willcock, S., Cuadros, S., Vanegas, M., Quintero, M., \& Torres-Vitolas, C. A. (2018). Hunters and hunting across indigenous and colonist communities at the forestagriculture interface: An ethnozoological study from the Peruvian Amazon. Journal of Ethnobiology and Ethnomedicine, 14, 54.

Frank, H. (2015). Toward zero-deforestation oil palm in Peru: Understanding actors, markets, and barriers (58 p). Lima: USAID.

Frison, E. A., Cherfas, J., \& Hodgkin, T. (2011). Agricultural biodiversity is essential for a sustainable improvement in food and nutrition security. Sustainability, 3, 238-253.

Fujisaka, S., \& White, D. (1998). Pasture or permanent crops after slashand-burn cultivation? Land-use choice in three Amazon colonies. Agroforestry Systems, 42, 45-59.

Fujisaka, S., Madrid, O., Hurtado, L., Usma, H., Ricse, A., Flores, Y., Idrogo, F., Barbarán, J., Arévalo, L., \& Labarta, R. A. (1999). Land use systems and dynamics in Pucallpa, Peru. In S. Fujisaka \& A. L. Jones (Eds.), Systems and farmer participatory research: Developments in research on natural resource management (pp. 22-29). Cali: Centro Internacional de Agricultura Tropical (CIAT).

Glinskis, E. A., \& Gutiérrez-Vélez, V. H. (2019). Quantifying and understanding land cover changes by large and small oil palm expansion regimes in the Peruvian Amazon. Land Use Policy, 80, 95-106.

Grivetti, L. E., \& Ogle, B. M. (2000). Value of traditional foods in meeting macro- and micronutrient needs: The wild plant connection. Nutrition Research Reviews, 13, 31-46.

Groves, R. M. (2006). Nonresponse rates and nonresponse Bias in household surveys. Public Opinion Quarterly, 70, 646-675.

Guevara Salas, S. (2009). Ucayali: análisis de situación en población. Lima: UNFPA, CIES

Gutiérrez-Vélez, V. H., \& DeFries, R. (2013). Annual multi-resolution detection of land cover conversion to oil palm in the Peruvian Amazon. Remote Sensing of Environment, 129, 154-167.

Gutiérrez-Vélez, V. H., DeFries, R., Pinedo-Vásquez, M., Uriarte, M., Padoch, C., Baethgen, W., Fernandes, K., \& Lim, Y. (2011). High- 
yield oil palm expansion spares land at the expense of forests in the Peruvian Amazon. Environmental Research Letters, 6, 044029.

Hansen, M., Potapov, P., Moore, R., Hancher, M., Turubanova, S., Tyukavina, A., Thau, S., Stehman, S., Goetz, S., Loveland, T., Kommareddy, A., Egorov, A., Chini, L., Justice, C., \& Townshend, J. (2013). High-resolution global maps of 21 stcentury Forest cover change, (15 November). Science, 342, 850853 Data available on-line from: http://earthenginepartners.appspot. com/science-2013-global-forest.

Hartung, C., Lerer, A., Anokwa, Y., Tseng, C., Brunette, W., \& Borriello, G. (2010). Open data kit: Tools to build information services for developing regions, in: Proceedings of the 4th ACM/IEEE international conference on information and communication technologies and development ICTD ' 10 . Presented at the the 4th ACM/IEEE international conference, ACM press, London, United Kingdom, pp. 1-12.

Hernández-Vásquez, A., \& Tapia-López, E. (2017). Chronic malnutrition among children under five in Peru: Spatial analysis of nutritional data, 2010-2016. Revista Española de Salud Pública, 91, 11.

INEI. 2017. Censos Nacionales 2017 - XII de Población, VII de Vivienda y III de Comunidades Indígenas. Perú perfil sociodemográfico. Informe nacional. Instituto Nacional de Estadística e Informática, Lima.

Jones, A. D. (2017). Critical review of the emerging research evidence on agricultural biodiversity, diet diversity, and nutritional status in lowand middle-income countries. Nutrition Reviews, 75, 769-782.

Jones, A. D., Shrinivas, A., \& Bezner-Kerr, R. (2014). Farm production diversity is associated with greater household dietary diversity in Malawi: Findings from nationally representative data. Food Policy, $46,1-12$.

Jones, A. D., Creed-Kanashiro, H., Zimmerer, K. S., de Haan, S., Carrasco, M., Meza, K., Cruz-Garcia, G. S., Tello, M., Plasencia Amaya, F., Marin, R. M., \& Ganoza, L. (2018). Farm-level agricultural biodiversity in the Peruvian Andes is associated with greater odds of women achieving a minimally diverse and micronutrient adequate diet. Journal of Nutrition, 148, 1625-1637.

Keding, G. B., Msuya, J. M., Maass, B. L., \& Krawinkel, M. B. (2012). Relating dietary diversity and food variety scores to vegetable production and socio-economic status of women in rural Tanzania. Food Security, 4, 129-140.

Kelley, L. C., Evans, S. G., \& Potts, M. D. (2017). Richer histories for more relevant policies: 42 years of tree cover loss and gain in Southeast Sulawesi, Indonesia. Global Change Biology, 23, 830-839.

Kennedy, G., Ballard, T., Dop, M. C., \& European Union. (2011). Guidelines for measuring household and individual dietary diversity (60 p). Rome: Food and Agriculture Organization of the United Nations.

Khoury, C. K., Bjorkman, A. D., Dempewolf, H., Ramirez-Villegas, J., Guarino, L., Jarvis, A., Rieseberg, L. H., \& Struik, P. C. (2014). Increasing homogeneity in global food supplies and the implications for food security. Proceedings of the National Academy of Sciences, $111,4001-4006$.

Labarta, R. A., White, D. S., \& Swinton, S. M. (2008). Does charcoal production slow agricultural expansion into the Peruvian Amazon rainforest? World Development, 36, 527-540.

Lachat, C., Raneri, J. E., Smith, K. W., Kolsteren, P., Van Damme, P., Verzelen, K., Penafiel, D., Vanhove, W., Kennedy, G., et al. (2018). Dietary species richness as a measure of food biodiversity and nutritional quality of diets. Proceedings of the National Academy of Sciences, $115,127-132$.

Lambin, E. F., Turner, B. L., Geist, H. J., Agbola, S. B., Angelsen, A., Bruce, J. W., Coomes, O. T., Dirzo, R., Fischer, G., et al. (2001). The causes of land-use and land-cover change: Moving beyond the myths. Global Environmental Change, 11, 261-269.

Lynn, P. (2018). Tackling panel attrition. In D. L. Vannette \& J. A. Krosnick (Eds.), The Palgrave handbook of survey research (pp. 143-153). Cham: Springer International Publishing.

Maechler, M. (2013). Cluster analysis extended Rousseeuw et al. R CRAN.
Magurran, A.E. (1988). Ecological diversity and its measurement. Princeton University Press, USA.

McKenzie, F. C., \& Williams, J. (2015). Sustainable food production: Constraints, challenges and choices by 2050. Food Security, 7(2), 221-233.

Ministerio de Agricultura y Riego. (2016). Plan Nacional de Desarrollo Sostenible de la Palma Aceitera en el Perú 2016-2025.pdf. MINAGRI, Lima, Perú.

Ministerio de Salud. (2014). Ucayali - Situación nutricional. Informe Ejecutivo. Instituto Nacional de Salud. Centro Nacional de Alimentación y Nutrición.

Ministerio del Ambiente. (2015). Cuantificación y Análisis de la Deforestación en la Amazonia Peruana en el Período 2010-20112013-2014. Ministerio del Ambiente, Lima, Perú. 108 p.

Murray, T.P. (2006). Rhythm of the rivers: An ecosystem approach to child nutrition and health on the Amazon frontier. Unpublished Doctoral Dissertation, College of Health and Science, University of Western Sydney, Richmond, NSW, Australia.

Pautrat, L. (2013). Empresas de palma aceitera deforestan 13076 hectareas de bosques primarios en los ultimos meses. Sociedad Peruana para el Ecodesarrollo (SPDA), Lima, Perú. 22 p.

Pautrat, L., \& Merveille, N. (2014). Incidencia de las políticas económicas en la transformación de la Amazonía peruana en un paisaje industrial. Universidad Antonio Ruiz de Montoya. Lima, Perú $22 \mathrm{p}$.

Perz, S. G., Aramburú, C., \& Bremner, J. (2005). Population, land use and deforestation in the Pan Amazon Basin: A comparison of Brazil, Bolivia, Colombia, Ecuador, Perú and Venezuela. Environment, Development and Sustainability, 7, 23-49.

Perz, S. G., Qiu, Y., Xia, Y., Southworth, J., Sun, J., Marsik, M., Rocha, K., Passos, V., Rojas, D., Alarcón, G., Barnes, G., \& Baraloto, C. (2013). Trans-boundary infrastructure and land cover change: Highway paving and community-level deforestation in a trinational frontier in the Amazon. Land Use Policy, 34, 27-41.

Pinstrup-Andersen, P. (2013). Nutrition-sensitive food systems: From rhetoric to action. The Lancet, 382, 375-376.

Piperata, B. A., Spence, J. E., Da-Gloria, P., \& Hubbe, M. (2011). The nutrition transition in Amazonia: Rapid economic change and its impact on growth and development in Ribeirinhos. American Journal of Physical Anthropology, 146, 1-13.

Popkin, B. M., \& Reardon, T. (2018). Obesity and the food system transformation in Latin America. Obesity Reviews, 19, 1028-1064.

Porro, R., Lopez-Feldman, A., W. Vela-Alvarado, J., QuiÑonez-Ruíz, L., P. Seijas-Cardenas, Z., Vásquez-Macedo, M., Salazar-Arista, C., I. NúÑez-Paredes, V., \& Cardenas-Ruiz, J. (2014). Forest use and agriculture in Ucayali, Peruvian Amazon: Interactions among livelihood strategies, income and environmental outcomes. Tropics, 23, 47-62.

Port Lourenço, A. E., Ventura Santos, R., Orellana, J. D. Y., \& Coimbra, C. E. A. (2008). Nutrition transition in Amazonia: Obesity and socioeconomic change in the Suruí Indians from Brazil. American Journal of Human Biology, 20, 564-571.

Radel, C., Schmook, B., \& Chowdhury, R. R. (2010). Agricultural livelihood transition in the southern Yucatán region: Diverging paths and their accompanying land changes. Regional Environmental Change, 10, 205-218.

Salazar, M., \& Rivadeneyra, D. (2016). Amazonía arrasada: El Grupo Melka y la deforestación en el Perú | Oxfam en Perú. Convoca, OXFAM. 33 p.

Salisbury, D. S. (2013). Mapa de Territorios Indígenas y Áreas Naturales Protegidas en las Fronteras Amazónicas entre Ucayali y Madre de Dios (Perú), Acre (Brasil) y Pando (Bolivia).

Schreckenberg, K., Torres-Vitolas, C.A., Willcock, S., Shackleton, C., Harvey, C.A., \& Kafumbata, D. (2016). Participatory data collection for ecosystem services research. A Practitioner's manual. (no. 003). ESPA working paper series. $127 \mathrm{p}$. 
Sherman, M., Ford, J., Llanos-Cuentas, A., Valdivia, M. J., \& IHACC Research Group. (2016). Food system vulnerability amidst the extreme 2010-2011 flooding in the Peruvian Amazon: A case study from the Ucayali region. Food Security, 8(3), 551-570.

Sibhatu, K. T., Krishna, V. V., \& Qaim, M. (2015). Production diversity and dietary diversity in smallholder farm households. Proceedings of the National Academy of Sciences, 112, 10657-10662.

Sierra Praeli, Y. (2017). Bosques de Ucayali: un botín para los traficantes de tierras en Perú [WWW Document]. Mongabay Environmental News. URL https://es.mongabay.com/2017/09/bosques-ucayalibotin-los-traficantes-tierras-peru/ (accessed 10.24.17).

Smale, M. (2005). Valuing crop biodiversity: On-farm genetic resources and economic change. CABI.

Springmann, M., Wiebe, K., Mason-D'Croz, D., Sulser, T. B., Rayner, M., \& Scarborough, P. (2018). Health and nutritional aspects of sustainable diet strategies and their association with environmental impacts: A global modelling analysis with country-level detail. The Lancet Planetary Health, 2, e451-e461.

Srinivas, A., \& Koh, L. P. (2016). Oil palm expansion drives avifaunal decline in the Pucallpa region of Peruvian Amazonia. Global Ecology and Conservation, 7, 183-200.

StataCorp. (2013). Stata statistical software: Release 13. College Station: StataCorp LP.

Swindale, A., \& Bilinksy, P. (2006). Household dietary diversity score (HDDS) for measurement of household food access: Indicator guide (version 2) 15.

Useche, P., \& Twyman, J. (2016). Sugar, fat, or protein: Are all food insecure households eating the same? The case of small Rice producers in Peru. In: Schmitz, A., Kennedy, P.L., Schmitz, T.G. (Eds.), Frontiers of Economics and Globalization. Emerald Group Publishing Limited, pp. 115-132.

van Dusen, M. E., \& Taylor, J. E. (2005). Missing markets and crop diversity: Evidence from Mexico. Environment and Development Economics, 10, 513-531.

Van Vliet, N., Mertz, O., Heinimann, A., Langanke, T., Pascual, U., Schmook, B., Adams, C., Schmidt-Vogt, D., Messerli, P., et al. (2012). Trends, drivers and impacts of changes in swidden cultivation in tropical forest-agriculture frontiers: A global assessment. Global Environmental Change, 22, 418-429.

VanWey, L. K., D’Antona, A. O., \& Brondizio, E. S. (2007). Household demographic change and land use/land cover change in the Brazilian Amazon. Population and Environment, 28, 163-185.

Vinceti, B., Termote, C., Ickowitz, A., Powell, B., Kehlenbeck, K., \& Hunter, D. (2013). The contribution of forests and trees to sustainable diets. Sustainability, 5, 4797-4824.

Walker, R., Perz, S., Caldas, M., \& Silva, L. G. T. (2002). Land use and land cover change in Forest Frontiers: The role of household life cycles. International Regional Science Review, 25, 169-199.

Waltner-Toews, D., \& Kay, J. (2005). The evolution of an ecosystem approach: The diamond schematic and an adaptive methodology for ecosystem sustainability and health. Ecology and Society, 10, 38.

Yanggen, D. (2000). Deforestación en la selva peruana. In: Perú: El Problema Agrario En Debate, SEPIA VIII, SEPIA (Seminario Permanente de Investigacion Agraria). Perú, pp. 579-608.

Zimmerer, K. S., de Haan, S., Jones, A. D., Creed-Kanashiro, H., Tello, M., Carrasco, M., Meza, K., Plasencia Amaya, F., Cruz-Garcia, G. S., Tubbeh, R., \& Jiménez Olivencia, Y. (2019). The biodiversity of food and agriculture (Agrobiodiversity) in the anthropocene: Research advances and conceptual framework. Anthropocene, 25, 100192.

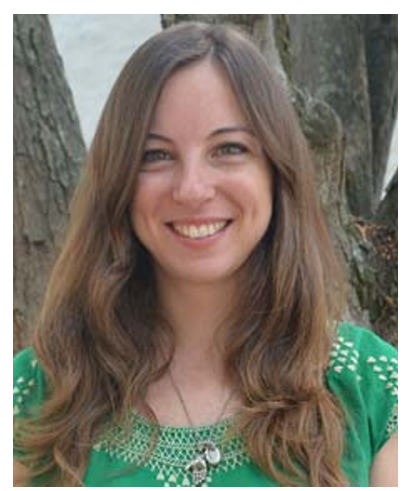

Genowefa Blundo-Canto is a development economist with expertise in impact assessment, economics of biodiversity and ecosystem services, socio-economics of agricultural biodiversity conservation on farm, and food and nutrition security. She holds a $\mathrm{PhD}$ in Environment and Development Economics from Roma Tre University (Italy). She is currently leading impact assessment work at the UMR Innovation of the French Agricultural Research Center for

International Development (Cirad)

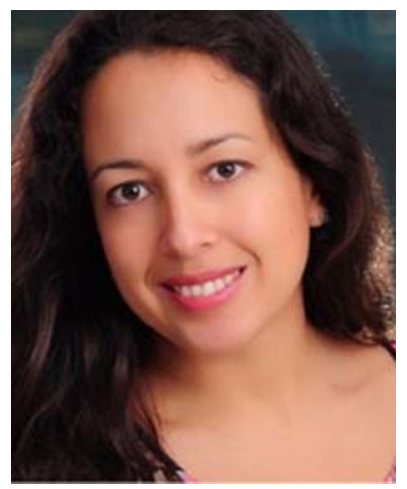

Gisella S. Cruz-Garcia is an ethnobiologist with expertise in food security and nutrition, biodiversity and natural resources, gender and rural development. She holds a PhD in Production Ecology and Resource Conservation and an MSc in Management of Agroecological Knowledge and Social Change from Wageningen University (The Netherlands). She is currently Pillar Lead on Neglected and Underutilized Species at Oxfam Novib and an associate researcher at the Botanical Research Institute of Texas (BRIT).

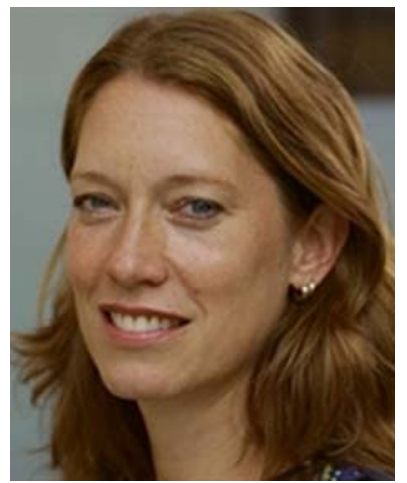

Elise F. Talsma is a nutritionist with expertise in human nutrition, public health, anthropometry and environmental toxicology. She holds a PhD in Human Nutrition from Wageningen University (The Netherlands). She is currently Assistant Professor at the Department of Agrotechnology and Food Sciences of Wageningen University (The Netherlands) 


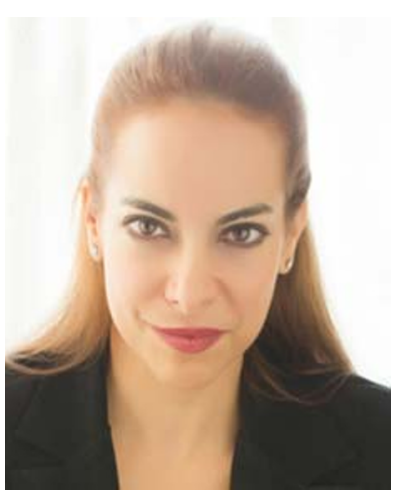

International Center for Tropical Agriculture (CIAT).

Wendy Francesconi is an environmental scientist with expertise in hydrological modelling, integrated landscape approaches to assess deforestation and ecosystem service provisioning, and evaluation of conservation practices in agriculture for ecosystem services. She holds a $\mathrm{PhD}$ from the School of Forest Resources and Conservation at the University of Florida (United States). She currently leads the Ecosystem services and environmental impacts team at the

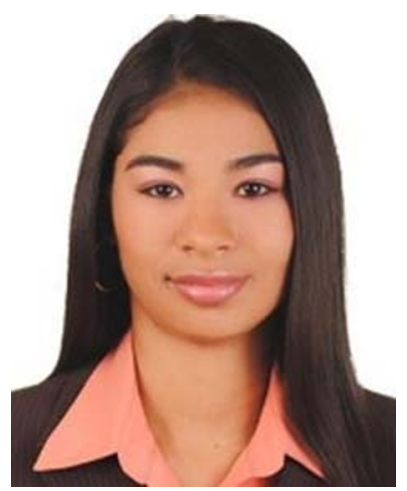

Lisset Perez-Marulanda is an economist with expertise in impact assessment, labor economics, and agricultural economics. She holds an MSc in economics from the ICESI University (Colombia). She is a research assistant for Agroecosystems and Sustainable Landscapes (ASL) research area at the International Center for Tropical Agriculture (CIAT).

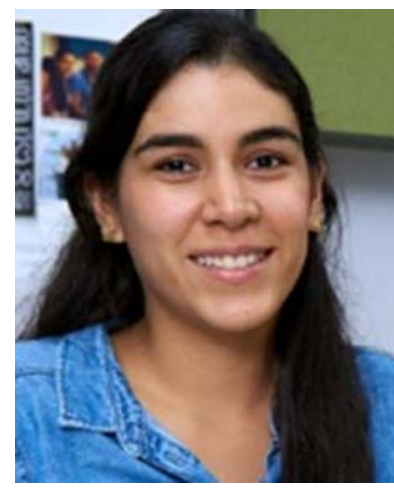

Paula Paz-Garcia is a data scientist with expertise in analysis of geospatial data and in Geographic Information Systems (GIS). She holds a BsC in Topographic Engineering from Universidad del Valle (Colombia). She is a research assistant for the Decision and Policy Analys is (DAPA) and Agroecosystems and Sustainable Landscapes (ASL) research areas at the International Center for Tropical Agriculture (CIAT).

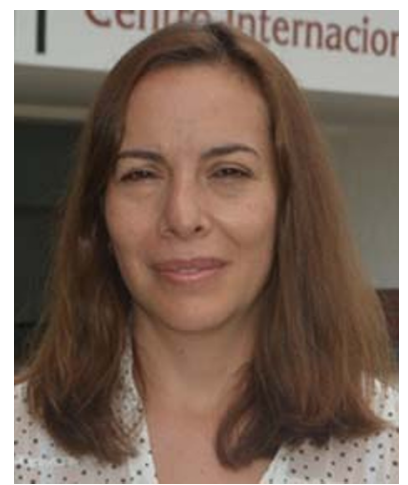

Marcela Quintero is an ecologist with expertise in ecosystem services, water resources management, hydrological modelling, and soil and water conservation. She holds a $\mathrm{PhD}$ in agronomy from the University of Florida. She is the Agroecosystems and Sustainable Landscapes Research Area Director for the International Center for Tropical Agriculture (CIAT) and co-leader of the CGIAR research program Water Land and Ecosystems' Restoring Degraded Landscapes flagship re-

search program 


\section{Affiliations}

\section{Genowefa Blundo-Canto ${ }^{1,2,3}$. Gisella S. Cruz-Garcia ${ }^{4,5}$ • Elise F. Talsma ${ }^{6,7}$ - Wendy Francesconi ${ }^{8} \cdot$ Ricardo Labarta $^{4}$. Jose Sanchez-Choy ${ }^{9} \cdot$ Lisset Perez-Marulanda $^{10} \cdot$ Paula Paz-Garcia $^{4} \cdot$ Marcela Quintero $^{10}$}

1 Decision and Policy Analysis Research Area, International Center for Tropical Agriculture (CIAT), Lima Office, Avenida La Molina 1895, La Molina, Apartado Postal 1558 Lima, Peru

2 UMR Innovation, French Agricultural Research Centre for International Development (CIRAD), 73 avenue Jean-François Breton, F-34398 Montpellier Cedex 5, France

3 University of Montpellier, F-34090 Montpellier, France

4 Decision and Policy Analysis Research Area, International Center for Tropical Agriculture (CIAT), Km. 17, Recta Cali-Palmira, Apartado Aéreo 6713 Cali, Colombia

5 Oxfam Novib, Postbus 30919, 2500 GX The Hague, The Netherlands

6 HarvestPlus, International Center for Tropical Agriculture (CIAT), Headquarters and Latin America and the Caribbean Regional Office, Km. 17, Recta Cali-Palmira, Apartado Aéreo 6713 Cali, Colombia
7 Division of Human Nutrition and Health, Wageningen University and Research, P.O. Box 9101, 6700

HB Wageningen, The Netherlands

8 Agroecosystems and Sustainable Landscapes Research Area, International Center for Tropical Agriculture (CIAT), Lima Office, Avenida La Molina 1895, La Molina, Apartado Postal 1558 Lima, Peru

9 Departamento Agroforestal Acuicola, Universidad Nacional Intercultural de la Amazonia, Yarinacocha, Peru

10 Agroecosystems and Sustainable Landscapes Research Area, International Center for Tropical Agriculture (CIAT), Km. 17, Recta Cali-Palmira, Apartado Aéreo 6713 Cali, Colombia 